\title{
Shaping Form: Performances as Analyses of Cyclic Macroform in Arnold Schoenberg's Sechs kleine Klavierstücke, op. 19 (1911), in the Recordings of Eduard Steuermann and Other Pianists
}

\author{
Christian Utz and Thomas Glaser
}

NOTE: The examples for the (text-only) PDF version of this item are available online at: https://www.mtosmt.org/issues/mto.20.26.4/mto.20.26.4.utz.php

KEYWORDS: analysis and performance, Arnold Schoenberg, corpus study of musical recordings, Eduard Steuermann, history of musical performance, Sechs kleine Klavierstücke, Six Little Piano

Pieces, op. 19

ABSTRACT: Arnold Schoenberg's Sechs kleine Klavierstücke (Six Little Piano Pieces), op. 19 (1911), offer a fruitful case study to examine and categorize performers' strategies in regard to their formshaping characteristics. A thorough quantitative and qualitative analysis of 46 recordings from 41 pianists (recorded between 1925 to 2018), including six recordings from Eduard Steuermann, the leading pianist of the Second Viennese School, scrutinizes the interdependency between macro- and microformal pianistic approaches to this cycle. In thus tracing varying conceptions of a performance-shaped cyclic form and their historical contexts, the continuous unfurling of the potential of Schoenberg's musical ideas in both "structuralist" and "rhetorical" performance styles is systematically explored, offering a fresh approach to the controversial discussion on how analysis and performance might relate to one another.

DOI: $10.30535 / \mathrm{mto} 26.4 .9$

Received January 2020

Volume 26, Number 4, December 2020

Copyright $\odot 2020$ Society for Music Theory

\section{The Mutual Productivity of Performance and Analysis}

[1.1] In his 2016 book Performative Analysis, Jeffrey Swinkin, makes the striking observation that it can hardly be the point of a musical performance to project or communicate analytical understanding. A performance might respond to an analysis of a certain work, just as an analysis might respond to a specific performance, but the end result will always be two autonomous interpretations, each impossible to reduce linearly to the other (25-27). Swinkin's view seems 
convincing at first, but in the end resigns itself to the impossibility of a concrete relationship between theory/analysis and performance. This arguably results from his method, which tends to proceed from theory to musical praxis, from analysis to performance, rather than in the reverse direction (Utz 2019b).

[1.2] It is here that the questions that motivated the PETAL research project (Performing, Experiencing and Theorizing Augmented Listening) arise: How might we intertwine musical analysis and practical performance in a way that leads to new understanding for both sides, ultimately reaching beyond their continuous polarization? This question, which Nicholas Cook had posed already in $1999,{ }^{(1)}$ remains difficult to answer today, despite a blossoming of new directions in musical performance studies in the last two decades. The intention of avoiding prescriptive analysis, which claims to derive a recipe for "correct" performance from the structure of the music, has led researchers to consider the value of moving from performance to analysis. Our research takes up this trend, and we especially attempt to further develop the idea that musical form is not grounded in the score alone, but - following the harpsichordist Robert Hill-is also brought forth by the performers "in real-time" (Hill and Mahnkopf 2015, 19). Expanding this idea, one might argue that musical form is constituted predominantly in the sounding event of a performance.

[1.3] The school of musical performance studies that has emerged around Nicholas Cook, Mine Doğantan-Dack, Daniel Leech-Wilkinson, and John Rink offers especially varied impulses for such an approach, though it also raises complex methodological problems. ${ }^{(2)}$ An important tendency of this scholarship is the attempt to break with the text-centered approach of traditional music theory and musicology, in the sense of the performative turn. The goal is not simply to compare or even adjudicate between performances seen merely as different "interpretations" of a fixed text, but rather to emphasize the autonomy of the performance with respect to its model. For Cook this shift leads to the concept of the "work as performance": the attempt to conceive of the work on the basis of the situatedness of performative agency (and not of a fixed text) (Cook 2013, 237-48; Utz 2015, 279). The possible interpretations of a "text," which might contain and/or allow countless different readings, are understood in their own right as valid works of art, not in service of but on equal footing with the text.

[1.4] Although we do not concur entirely with Cook's conclusions, we are guided by the hypothesis that varying conceptions of the performance of the large-scale form of a work can fundamentally shape both the perception and (music-theoretical) analysis of this form and can lead to markedly different interpretational consequences. At the same time, we aim to point to the complex interaction of interpretative decisions with historical discourses and tropes of the music's reception. Our research thus attempts to demonstrate that in addition to being historical documents in their own right, practical, sounding interpretations can exhibit fully valid analyses of a work (Cook 1995; Lester 1995). This sounding evidence can be treated on a par with musictheoretical analyses or written historical documents with mutually fruitful results. We ultimately consider a musical text and its sounding performance(s) as central representations of a musical work. ${ }^{(3)}$ By positing a continuous interaction between performance and analysis, this article aims at investigating performance strategies towards cyclic (macro-)form. While we have taken efforts not to prejudice recorded performances by analytical insights gained beforehand, we acknowledge that performances occur in a discursive space in which (implicit or explicit) analytical thought is continuously present - for example, by aspects of "informed intuition" (Rink 2002, 36) on which performers build their sounding interpretations.

[1.5] Throughout our investigations, the large-scale form of complex, cyclical works has occupied the center of our attention. ${ }^{(4)}$ We have examined and categorized performers' strategies systematically in regard to their form-shaping characteristics, understanding microform and macroform as closely interdependent, and in this way aimed to challenge a frequent thesis of recent musicological literature: that large-scale form is largely irrelevant for the perception and performance of music. ${ }^{(5)}$ For Leech-Wilkinson, for example, "long-term structures are theoretical, useful for composers, an invitation from analysts to imagine music in a particular way, but apparently not perceptible (save in the vaguest outline via memory)" (2012, [4.10]). On the other hand, Doğantan-Dack observed as early as 2008 that "the way a performer handles local details is 
very much related to her conception of large-scale relationships - or her lack thereof" $(2008,305)$. We therefore proceed on the assumption that the relationship of micro- and macroform between the poles of performance and analysis holds many as yet unanswered questions that shall be scrutinized in the following discussion.

\section{Arnold Schoenberg's Sechs kleine Klavierstücke, op. 19, as a Case Study}

[2.1] Arnold Schoenberg's Sechs kleine Klavierstücke (Six Little Piano Pieces), op. 19, from 1911 offer a particularly promising case study. Several early recordings are available from pianists close to the Schoenberg school, for which a close link between structural analysis and pianistic interpretation can be assumed. Particularly noteworthy are the six recordings by Eduard Steuermann, which Christian Utz (forthcoming) has considered in detail in their historical context in a separate article. Also, the short duration of these pieces allows a detailed evaluation of a relatively large number of different recordings. The following investigation is based on both quantitative and qualitative analyses of 46 recordings from 41 pianists, including the six by Steuermann $(1949,1954,1957 \mathrm{a}$, 1957b, 1962, 1963) and 40 other recordings stretching from 1925 to 2018, each by a different pianist (Example 1). With the exception of three live recordings by Steuermann and three recordings made for the PETAL project, only published recordings were considered. Selections were based on the criteria of historical balance (we considered approximately the same percentage of recordings for each decade, from the 1920s to the present), international relevance and prominence of the performer, and availability of the recordings. ${ }^{(6)}$

[2.2] Furthermore, in a workshop with three pianists, we discussed the shaping of the cycle in performance, documented the pianists' particular strategies, and attempted to understand them from a historical perspective. ${ }^{(7)}$ In preparation for this workshop, an annotated score of Schoenberg's op. 19 was created, to which the following analyses will make frequent reference. This score, which is freely available online, combines analytical accounts and tempo-graphs with a musical text that integrates variant readings from the first autograph and autograph fair copy in different colors. ${ }^{(8)}$ In the following exposition, we start with the historical context and the question of a historically informed interpretation of the cycle and then correlate varying pianistic strategies of macro- and microformal molding.

\section{A. Cyclical Potentials in Schoenberg's op. 19}

[2.3] Schoenberg wrote five of the six pieces of the Klavierstücke, op. 19, in a single day (19 February 1911). The sixth, however, came almost four months later on June 17, likely in response to Gustav Mahler's funeral on May 22, also the subject of one of Schoenberg's paintings from the same time period (Stuckenschmidt 1977, 108, 137-38; Massow 1993; McKee 2005). A fair copy in Schoenberg's hand and the first printed edition of the six pieces contain only minor revisions. The short cycle (with a total duration of around five minutes) is one of Schoenberg's few contributions to the genre of (usually cyclically ordered) short pieces adopted far beyond the Second Viennese School between 1909 and 1914, a reaction to the so-called "Mammutismus," that was popular in the decades around 1900 (and to which Schoenberg's Gurre-Lieder -also completed in 1911-were a substantial contribution) (Obert 2008, 79-83; Taruskin 2010, 1-58). Along with the Five Orchestral Pieces, op. 16 (1909), these six piano pieces document in a particularly concentrated form an aesthetic of "phraselessness" [Phrasenlosigkeit], of the "exclusion of everything secondary and derived" [Ausscheidung von Sekundärem, Abgeleitetem], of "concentration on the essential" [Konzentration auf Wesentliches], and of the "suppression of techniques of mediation (for example repetitions)" [Ausschaltung von Vermittlungen (wie etwa Wiederholungen)] (Obert 2008, 150). ${ }^{(9)}$ This aesthetic had developed in the Second Viennese School since 1906 in connection with, among other things, Karl Kraus's language criticism.

[2.4] Regarding the creative process, the first question that presents itself is whether Schoenberg could have already viewed the first five pieces as a cyclical unit. A few observations can be of use here. The underlying eighth note pulse of nos. 1 and 5 can be seen as a common "frame," while the pieces lying between them follow a quarter note pulse. No. 1, the longest piece and the most 
motivically and thematically complex, suggests relatively clearly the contours of a sonata form. ${ }^{(10)}$ It can thus be seen as a typical "first movement," carrying a certain weight in the cycle. ${ }^{(11)}$ The last chord of no. 5 is in turn characterized by a decided finality: it is preceded by a penultimate chord with a leading, anacrustic effect and prepared by a prolonged and dynamically prominent cadence (mm. 12-15).

[2.5] The addition of the temporally expansive sixth movement ("sehr langsam"), however, establishes a framing effect with the first piece. This renders movements $2-5$ as intermediate movements. The sixth piece can thus be understood, on the one hand, as part of a formal frame, particularly if seen as sketching the (admittedly extremely compressed) contours of a sonata form once again. On the other hand, it can be understood (already in the context of its production) as "extraterritorial." A close relationship to Gustav Mahler's Ninth Symphony - absent in the first five movements - speaks for this second understanding. ${ }^{(12)}$ And in fact the decision to end op. 19 with a slow movement is itself a reference to the gradually fading Adagio that closes the symphony.

[2.6] The four inner movements can be grouped in consecutive pairs, whereby each pair is characterized by gradations of a single tempo category: nos. 2 and 3, "Langsam" - "Sehr langsame quarter note"; and nos. 4 and 5, "Rasch, aber leicht" - "Etwas rasch." This succession of slow and fast (dance-like) "movements" is reminiscent of the succession of adagio and scherzo movements in sonata and symphonic forms.

[2.7] Cyclic cohesion is also constituted by means of pitch relationships between the individual pieces. The final chords of nos. 1, 2, and 5 are each related by half step to their "neighbor chords" at the beginnings of nos. 2, 3, and 6 respectively (see the annotated score). In this way, a rupture is staged around the fourth piece, the only piece not connected by such chords to its neighbors. ${ }^{(13)}$ The strongly contrasting characters of the third and fourth pieces reinforce this rupture. Further cross-movement structural coherences have been extensively discussed in the critical literature since the 1920s. ${ }^{(14)}$ This type of structural analysis aiming for coherence has found particularly rewarding models in the works of the Second Viennese School. Nonetheless, the spontaneous character of the work's composition and an aesthetic of the subconscious strongly suggest an individualization and emancipation of the detail from its cyclical context. ${ }^{(15)}$ A tendency towards Roland Barthes's "cycle of fragments" (1986a, 1986b, and 1986c; see also Sprau 2017), towards the bursting of formal unity, stands in tension with conventional techniques of cyclical integration.

\section{B. Schoenberg's op. 19 in the Context of the Performance Practice of the Schoenberg School}

[2.8] To contextualize our discussion of the relation of detail to totality in the individual recordings, we begin by briefly recapitulating the relationship between analysis and performance as understood by the Schoenberg School. It would be too simplistic to describe this tradition as straightforwardly text-centered or analytical, reducing it to a "telepathic fantasy," an idealized direct communication between composer and listener that views the process of performance as largely dispensable and thus deliberately disregards the social dimension of music making. ${ }^{(16)}$ Adorno, on the contrary, describes a clear difference between analysis and performance:

True reproduction is not simply a realization of the results of analysis (incidentally, these results should not be thought of as conclusive). It rather contains the idiomatic element sublated within itself. And it thus necessarily encompasses the performer's subjectivity, which presents the idiomatic element in relation to every work [. . .]. So it is neither irrational (idiomatic) nor a chemically pure, analytical reproduction, but rather the reinstatement of the mimetic element achieved by passing through the analytical. $^{(17)}(2006,69)$

Analysis is thus the prerequisite but not the sole reference point for any single performance. For the Schoenberg School, it serves to establish a framework for the following principles (among others): (1) freedom and simultaneously fidelity with respect to the preserved "authority" of the score; (2) a fundamental orientation toward vocality [Gesangliches], toward cantabile, in instrumental as well as vocal music; and (3) clarity of performance, achieved through a 
differentiated agogics, the prohibition of a "scanning" of accents, and the emancipation of the parameter of tempo. ${ }^{(18)}$ Generally speaking, in question is an interlocking of the work-text with its realization by a performer through knowledge of aspects of performance that are not or cannot be notated.

[2.9] Particularly striking in relation to the Schoenberg circle's performance aesthetic of the op. 19 piano pieces is Schoenberg's instruction, complete with an exclamation mark, at the beginning of the score: "After each piece an extended pause, the pieces must not blend into each other!"(19) This direction is absent from the first autograph and fair copy and could therefore have been a reaction to the first private and public performances ${ }^{(20)}$ - performances that Schoenberg found not entirely satisfying. In a diary entry dated January 22, 1912, Schoenberg complained in this vein about a private performance by Busoni's pupil Egon Petri (1881-1962): “In general he took everything too fast; or rather too hastily. I said to Webern: One must have time in my music. It is not for people who have other things to do. At any rate it is a great pleasure to hear one's pieces played by someone who can master them perfectly from a technical point of view" (Stuckenschmidt 1977, 156). ${ }^{(21)}$ And again Schoenberg seemed dissatisfied with the first public performance by Louis Closson (1886-?), another Busoni pupil: the tempi were too fast, and Closson failed to pause between the pieces (157).

[2.10] It seems likely that Schoenberg was motivated in these reactions by the desire for each of the six pieces to stand independently in a performance. The pianist therefore should avoid, against the standard practice at this time for cyclical works, taking the pieces in a single flow through breakless transitions. ${ }^{(22)}$ As with Barthes's reading of Schumann's cyclical piano works and Schubert's Winterreise, D. 911, an interpretation that understands cyclicality not only through coherence, but also through a drifting apart, or a tendency towards fragmentariness of the individual movements, can thus also be justified in the case of Schoenberg's op. 19. However, it is beyond question that the six pieces, due to their brevity, together form an overarching formal constellation, whose short, ca. five-minute duration allows a graspable whole to emerge-a whole whose (six-limbed) anatomy is reinvented by each new performer.

[2.11] Eduard Steuermann (1892-1964), who after the premiere of Pierrot lunaire in 1912 became the preferred pianist of the Schoenberg school, made six recordings of op. 19 between 1949 and 1963 (including three live recordings at the Darmstadt Summer Courses in 1954 and 1957, and the International Summer Academy of the Mozarteum Salzburg in 1962). All of these are marked by relatively compressed total durations (the average total duration of the six Steuermann recordings is 4:39, compared to 5:14 across 40 recordings by other pianists; see Example 2). The same applies for Karl Steiner (1912-2001), another pianist closely connected to the Schoenberg school, whose recording is the shortest of the sample of measured recordings (1962, total duration 3:58), and for Else C. Kraus (1890-1979), who had premiered Schoenberg's Piano Pieces, op. 33a and op. 33b, and recorded op. 19 (for the second time) in 1960 (total duration 4:07). Whether this reflects a specific practice of the Schoenberg school (which Schoenberg's objection to Petri and Closson's "hurried" tempi seems to contradict) or rather a general tendency of earlier recordings (up to the 1960s) towards faster tempi-as otherwise well documented (see Philip 1992, 35-36) - need not be decided here.

[2.12] In a letter from July 24, 1942 to his then 15-year-old nephew Michael Gielen (1927-2019), Steuermann gave detailed instructions for the interpretation of op. 19. ${ }^{(23)}$ Steuermann's advice aims for a "large arc," at least within each of the six pieces, and formulates specific instructions for the performance of many details. Characteristic of Steuermann's remarks is an oscillation between the requirements of a "unity of tempo" (also supported by metronome markings for each pieceeven if their bindingness is relativized) and a "unity of movement" that would follow the individual phrases. The contradictoriness of the categories "main tempo" and "unity of tempo," to which the Schoenberg school felt entirely obligated (Haack 2002), also comes sharply into focus in Adorno's $(2006,102)$ sketches for a theory of musical reproduction.

[2.13] The tension between "unity of tempo" and "unity of movement" could also be responsible for the fact that the metronome markings suggested by Steuermann in his letter to Gielen are almost uniformly faster than the tempi realized in his recordings-tempi, which-as mentioned 
above-are already among the shortest in this history of the work's recording. As Example 2 also shows, however, Steuermann's deviations from the mean tempi of the compared 40 recordings are anything but flagrant, with the exception of the third piece (the average across all six Steuermann recordings in this piece lies at 49.5 beats per minute (bpm), markedly above the average across the 40 compared recordings at $37.5 \mathrm{bpm}$ ) and the fifth piece, where his average tempo of $111.1 \mathrm{bpm}$ is significantly below the average of the other interpreters at $142.4 \mathrm{bpm}$ (as well as below the tempo suggested in the letter to Gielen, $144 \mathrm{bpm}) .{ }^{(24)}$ A specific cyclical dramaturgy can thus be surmised, (25) wherein the fast shaping of no. 3 and slow shaping of no. 5 particularly distinguish

Steuermann's interpretation. In the following discussion, we will consider especially the last of Steuermann's six recordings, the studio recording from 1963. This is justified by the fact that one can see this last recording as a sort of "legacy," which in many respects, speaks with the greatest sovereignty. At the same time, this recording's deviations from his mean values are especially low: the six durations deviate merely between zero and three seconds from the mean values, and deviations from the average main tempi are also especially low (Example 2). This is also the reason for reducing the six Steuermann recordings to the one from 1963 in the calculation of mean duration and tempi most often used as comparative values in the following discussions. Tables and figures variably show mean values of all 46 recordings (including all six recordings from Steuermann), 41 recordings (including only Steuermann 1963), or 40 recordings (excluding all Steuermann recordings, mainly used to highlight the particularities of his interpretation in section $4)$.

[2.14] The following discussion first proceeds in a sort of "top-down" method, starting with an interpretation of the quantitative results ("distant listening") that pertain to the macroform of the entire cycle. ${ }^{(26)}$ We will differentiate several distinct dramaturgies on the basis of the absolute durations of the individual pieces and their percentage values of the total duration (section 3). This is followed by a qualitative description of individual recordings ("close listening") for each of the six pieces (section 4), with special emphasis put on the interaction of detail and whole in the creation of "performed form." Steuermann's recording from 1963 serves here to lead and orient the discussion. In conclusion, Steuermann's position in the performance history of op. 19 will be considered, and the complexity of connections and divergences in this performance history in the context of a performative analysis of the cycle will be demonstrated (section 5).

[2.15] As several recent studies in the field have shown (Epstein 1995, 99; Laubhold 2014, 69), tempo and duration are significant categories when evaluating large corpora of recordings. Nevertheless, these cannot provide comprehensive insights into the recorded performance history of a musical work. Methodologically, our research does not only rely on the collection and analysis of numerical data, but also includes a close listening and aesthetic description of sounding phenomena. We do not claim that tempo choices are exclusively vehicles of musical structure; they may also be (and have often been described as) means of musical expression in combination with the shaping of dynamics. ${ }^{(27)}$ As the analyses below demonstrate, it is not always clearly discernable whether a performative choice is made out of structural and/or expressive considerations. Moreover, there is the additional problem of assuming that an "expression" calls for a hermeneutic interpretation (e.g., What kind of expression? What is being expressed?), as formal or structural implications of a performance to some extent can be considered "expressive" in their own right. ${ }^{(28)}$ Although we repeatedly point at such implications, we generally refrain from speculative and arbitrary hermeneutic interpretations, leaving our analyses open to some extent. We also seek to avoid applying preconceived models of musicological interpretation and performance studies such as "espressivo," "neo-objective," or "historically informed" (see Stenzl 1995 and section 5 below) to any single recorded performance. Despite this skepticism towards the possibility of ascertaining a work's expressive "content," our analyses aim at providing criteria for discussing recorded performances with regard to their aesthetic (and historical) value and relevance.

\section{Macroformal Models in Recordings of Schoenberg's op. 19}


[3.1] A chronological representation in scatter plot form of the total durations of all 46 considered recordings allows the derivation of general trends in the performance history of op. 19, such as a general decrease in tempi and increase in duration, to be interrelated with the individual interpretations of each pianist (Example 3). In this way it becomes evident that the very fast tempi of the earliest recordings by Walter Gieseking (1925) and Jesús María Sanromá (1937) endure well into the 1970s, most notably in the already mentioned recordings by Steuermann (1957a), Kraus (1960) and Steiner (1962), but also Pál Kadosa (1958) and Otto Zykan (1970). On the other hand, Mitsuko Uchida (2000) and Christoph Eschenbach (2000) are especially extreme examples of a tendency towards longer total durations as a particular characteristic of the 2000s: in both interpretations the duration of each individual movement of the performance is (mostly markedly) above the average across the 41 recordings, with Eschenbach's second and Uchida's sixth movement as maxima (Example 4). The significant difference between the total durations of these two recordings and all the others (7:22 for Uchida and 6:42 for Eschenbach, exceeding the third longest recording, Chen 1996 at 6:08, by 1:14 and 0:34 respectively) lends them an extraterritorial and indeed, at times, eccentric character.

[3.2] We proceed now to a more precise comparison of macro-formal strategies. Example 4 shows the absolute duration of every movement in each of the 46 recordings (left), as well as the percentage of the recording's total duration constituted by each movement (right; referred to in the following as "percent value"). Red shading indicates the position of each value in a gradated scale of all recorded values in each column (dark red = highest value, white = lowest value). The variation in percent value among the 41 recordings (given as a relative standard deviation) is significantly less for nos. 1, 2, 3 and 6 (between 11.6\% and 14.7\%) than for no. 4 (18.7\%) and no. 5 $(21.2 \%)$. To put it another way, the relationship between the durations of the two "scherzo" movements and the four other movements seems to be an important factor in discerning clear differences between the recordings. The absolute duration, on the other hand, varies most noticeably in nos. 2,5 , and $6(20.9 \%-25.5 \%)$, while no. 1 , here as in the case of the percent value, shows the least variation (13.3\%, $11.6 \%$ for the percent value). In view of the opening movement's protean form, the lack of exact tempo markings, and the extreme fluctuation of the written-out rubati, this result is nothing short of astonishing. It may suggest that extreme tempi are rarely selected for this opening movement, and that the gestural-thematic character of its formal structure to some degree motivates a tempo-dramaturgical consensus (which does not exclude extreme tempo strategies in this piece, as will be seen below).

[3.3] Comparing these tables with Example 5 and Example 6, we derive five basic models of cyclical dramaturgy, which will provide a concrete context for the individual approaches of each pianist. We call them the frame model, opening model, finale model, contrast model, and accelerando model. As will quickly become evident, these models are ideal types that allow a diversity of hybrids and intermediaries, although in individual cases they can be strikingly pronounced. On the whole, these categories should be understood as the starting point, not the goal of the discussion. For there are of course many factors besides the duration of the individual movements and their proportional relationships that contribute to the "weight" of a single piece or section. It would be imaginable, for example, to attribute a particular perceptual weight to a piece taken unusually fast and pointedly, suggesting that a condensing of the musical flow takes on a substantial (memory) function for the macroformal orientation of the listener as an "imprint" (see Deliège 2001 on the relevance of imprints for the perception of macroform). This aspect is particularly relevant for the contrast model (see [3.11]).

[3.4] The frame model seems to be particularly pronounced in several recordings. Where nos. 1 and 6 make up approximately the same percentage of the total duration, the frame model is present. The more emphatically these framing movements distinguish themselves from the inner movements, the more clearly the frame model emerges. It is certainly not by chance that the total durations of several recordings approaching this model are significantly higher than the mean value 5:13 (Schleiermacher 1994: 6:00; Bucquet 1973: 5:56; Hill 1996: 5:31; also compare Wolpe 1991: 6:01). Schleiermacher carries the symmetrical principle of the frame model to an extreme (Example 7): the outer frame pieces, nos. 1 and 6, are strongly weighted, and the inner frame pieces, nos. 2 and 5, more moderately weighted, while the percent values of the inner pieces, nos. 3 and 4 , lie 
significantly below the average $\left(15.2 / 18.9 ; 5.0 / 6.8^{(29)}\right)$. As Schleiermacher's overall conception of the piece implies broader tempi, the absolute durations of these inner movements are only slightly below the mean duration (no. 3: 0:55/0:59; no. 4: 0:18/0:21). A clear difference between the percent values of the frame pieces and those of the inner pieces is also most clearly pronounced for Schleiermacher (a minimal difference of 7.9 lies between the shorter frame value, for no. 1 , at $25.8 \%$ and the longest inner value, for no. 2 , at $17.9 \%$ ).

[3.5] Other examples of the frame model tend towards what we will generally call the contrast model (see [3.11]). This model is characterized by a single, or sometimes several sharp tempo contrasts between individual pieces. In Claude Helffer (1969) for example, the durations of nos. 1, 2,3 , and 6 converge to such a degree (percent values between 19.6 and 22.9 , in total $84.5 \%$ ), that nos. $4(0: 20 / 0: 21 ; 6.4 / 6.8)$ and $5(0: 29 / 0: 29 ; 9.0 / 9.2)$ stand out markedly in their relative brevity, although they are very close to the mean values (Example 7). This requires a rather slow interpretation of the second (1:05/0:54) and third pieces (1:02/0:59), and a relatively faster interpretation of the first (1:13/1:16) and sixth pieces (1:09/1:14). Perhaps such a conception, in which the durations of nos. 1, 2,3, and 6 converge, can also be likened to Barthes's conception of a "cycle of fragments," insofar as it in fact leads to a lack of clear macroformal architecture-maybe with the exception of the contrastive function of the fourth and fifth pieces.

[3.6] The opening model and finale model can be understood as variants of the frame model, accentuating the first and final movement respectively. The opening model is particularly pronounced in six recordings; here the highest percent values in the first piece (mean: 24.5) coincide with the maximal differences between the percent values of the first and sixth pieces (mean: 1.2): Majlingová 1977 (31.8; difference 12.3(30)), Harris 1951 (31.1; 14.8), Dünki 2005 (29.2; 10.6), Zykan 1970 (28.9; 7.9), Kadosa 1958 (28.6; 9.3), and Kraus 1960 (26.7; 7.6). Of these, only Johana Harris (maximum duration at 1:37/1:16; main tempo 57.1/87.6 ${ }^{(31)}$ ) and Lýdia Majlingová (1:33/1:16; 70.5/87.6) give the first piece a halting, dream-like character. ${ }^{(32)}$ In the case of JeanJacques Dünki (1:24/1:16; 71.8/87.6 $\left.6^{(33)}\right)$, the intention of achieving a transparent formal structure through small breaks and by letting the cadencing chords resonate is audible, ${ }^{(34)}$ although a "flowing movement in the style of a romantic barcarole" [fließende Bewegung in der Art einer romantischen Barcarole] (Dünki 2006, 122) should predominate. For Dünki as well as Pál Kadosa (1:13/1:16; 89.1/87.6), Otto Zykan (1:10/1:16; 92.7/87.6), and Else C. Kraus (1:06/1:16; 82.7/87.6(35)), the opening model is part of a fast, synoptic interpretation of the cycle (total durations Kadosa 4:16, Zykan 4:01, Kraus: 4:07, Dünki: 4:49; mean 5:13).

[3.7] With its high instability of tempo (relative standard deviation from the main tempo for no. 1: 31.1/24.9), Kraus's approach can thus be tied to interpretations from the 1920s and '30s, especially those of Walter Gieseking 1925 (31.4) and Jesús María Sanromá 1937 (37.2) in contrast to Dünki (24.2/24.9). ${ }^{(36)}$ Despite this difference, the opening model is distinctive in both Kraus and Dünki (Example 8): the quick, fleeting character of their interpretations of the following five pieces (clearly more extreme in Kraus than in Dünki) underscores the variety and structural complexity of the first piece as a distinguishing characteristic. The swift conception of the second piece-a contrasting moment that strengthens the solemn prominence of the first piece-is a crucial factor here.

[3.8] The finale model, in view of the possible relation of the cyclical dramaturgy of Schoenberg's op. 19 to Mahler's Ninth Symphony pointed to above, can perhaps be considered the most conventional. The expansion of the sixth piece clarifies its concluding function, which, depending on the shaping of the previous pieces, may imply a more or less extraterritorial character. The finale model is particularly pronounced where a high percent value of the sixth piece accompanies a particularly low percent value of the first piece. As already suggested above, Mitsuko Uchida 2000 illustrates this case particularly clearly (difference $13.9 ;{ }^{(37)}$ no. $1: 18.2 / 24.5 ; 1: 21 / 1: 16 ; 105.0 / 87.6$ bpm; ${ }^{(38)}$ no. 6: 32.1/23.3; 2:22/1:14; 18.6/39.0 bpm) (Example 9). The other interpretations that approach this model exhibit a significantly smaller difference between the sixth and first pieces: Chen 1996 (6.0), Sherman 1999 (3.9), Skogstad 2018 (3.9), and Eschenbach 2000 (3.7). In these cases, one might speak of a hybrid of the frame and finale models. 
[3.9] For Uchida, the accentuation of the final movement is accomplished through an extremely slow tempo, which results in a duration of 2:22 for no. 6, 38 seconds longer than the second slowest interpretation (Pi-hsien Chen 1996, 1:44) and 1:35 longer than the fastest interpretation (Kraus 1960, $0: 47)$. The music comes to a standstill; the palpably solemn, commemorative character-quasi in memoriam Mahler-gives Uchida's no. 6 an unambiguous extraterritoriality. In nos. 3 and 5, Uchida also reaches very long durations, both of which near the respective maxima. However, the percent values for these movements are hardly conspicuous, as they are neutralized by the extreme expansiveness of no. 6. Aleksei Liubimov 1971 (Example 9), like Kraus and Dünki and in contrast to Uchida, takes a quicker than average interpretation as a starting point, especially in no. 1, where his main tempo is the fastest of all recordings considered $\left(132.0 / 87.6^{(39)}\right)$, as well as in no. 4 (0:17/0:21) and no. 5 (0:22/0:29), whose contrastive characters are preserved by means of a comparatively slow no. 3 (1:00/0:59). A commonality between Liubimov and Uchida is the similarity of the percent values for nos. 1, 2, and 3 (Uchida: 18.2-16.3-17.9; Liubimov: 19.3-18.021.2), which gives rise to a tripartite grouping $1-3 / 4-5 / 6$ (Liubimov) and 1-3/4/5-6 (Uchida).

[3.10] The consequence of a relatively short length of no. 1 is thus, inversely to the opening model, that the first piece moves closer to the inner pieces in duration, or can even be exceeded by them. A particularly spectacular example of this is Christoph Eschenbach 2000, the only recording where the second piece is longer than the first (no. 1: 1:23/1:16; no. 2: 1:25/0:54). Thus Uchida's and Eschenbach's interpretations effectively mirror the distinctive manifestations of the opening model: they forego a sharp contrast in the fourth and fifth pieces and assimilate the durations of the first three, so that -despite a generally slow overall tempo-the solemn character of the final piece is particularly forceful (Uchida: 1:21-1:12-1:19-0:22-0:46-2:22; Eschenbach: 1:23-1:25-1:15-0:24-0:371:38). A further interpretational strategy recognizable here is the formation of (a) an axis 1-3 (in Liubimov the third piece, at 1:00, is longer than the first, at 0:55), (b) 3-6 (the respective approaches in representatives of the opening model), or (c) a three-part framing 1-3-6.

[3.11] The last of these dramaturgies is ultimately best described as a contrast model. This model can take on various forms, but usually proceeds by sharpening the expanded frame model 1-3-6. These three movements tend to be strongly weighted in some recordings, with nos. 2 and/or 4 and 5 forming striking contrasts. This model thus must be distinguished from various contrast effects described above, which function as part of the models already laid out: shortening no. 2 reinforces the opening model, shortening nos. 4 and 5 the finale model, and a general shortening of the inner movements is characteristic of the frame model. The condition of an autonomous contrast model is thus a distinctive similarity in the durations of nos. 1,3, and 6, whose architectonic pillar function is strengthened by contrasting intermezzi, nos. 2,4 , and 5 .

[3.12] Paul Jacobs's recording from 1958 is the only example in which the third piece is longer than both the first and sixth (01:15-01:07-01:25-00:15-00:26-01:12). The extreme contrast between the third piece, with the longest duration of all the recordings (1:25/0:59), and the fourth piece, with the shortest (0:15/0:21), gives particularly forceful expression to the caesura function of the fourth piece, as described in the analytical outline above (see [2.7]). This recording is however not paradigmatic of the contrast model, as Jacobs takes the second piece somewhat slowly. Unmistakable is the contrast model in Herbert Henck 1994 (24.7-13.8-23.3-5.6-5,6-26.9; total duration 5:19), and clear also in Aribert Reimann 1984 (23.6-13.9-21.5-6.0-9.1-25.9; total duration 5:12). Example 10 shows how this model takes shape in these two recordings in comparison to the average tempo-values. A difference between Henck and Reimann is the handling of the fifth piece, which in Reimann, as in almost all recordings, is taken more broadly than the fourth $(4: 0: 19 / 0: 21 ; 5$ : 0:28/0:29). In Henck however, the durations of nos. 4 and 5 are identical (5.6\%, 0:18), which necessitates an extremely fast tempo in no. $5(197.2 / 141.6)$ and thus sharpens the contrast between nos. 5 and $6 .{ }^{(40)}$

[3.13] Finally, the accelerando model most distinctively follows the principal of a "large arc" (Example 11). Jesús María Sanromá's early recording (1937) shows it in especially "pure" form: in nos. 1 through 5, each piece is shorter and thus proportionally less weighted than the previous, with balance restored only by the sixth piece (24.0-20.5-18.0-7.7-6.8-23.1; 1:04-0:54-0:48-0:20$0: 18-1: 01$; total duration 4:25). Thus, in a certain way, the compositional process is reproduced, in 
which nos. 1-5 were composed in one go. This conception requires a relatively broad tempo for no. 1 , accentuating the expositional character of this movement; a rather brisk, "anti-romantic" concept of no. 3-this being the essential difference from the contrast model; and possibly (only in Sanromá 1937 and Boffard 2013) a final outpacing of no. 4 by no. 5. This model, as is clearly the case in Sanromá, can allude to the frame model: the sixth piece balances a weightier beginning after an intermediate, accelerating chain of events. This can also be seen in Steuermann 1963 (23,1-17,315,2-6,9-13,0-24,5; 1:04-0:48-0:42-0:19-0:36-1:08; total 4:37; see Example 11) where, however, the expansion of no. 5 gives rise to a specific, highly individual dramaturgy (explored in detail in section 4 below) that should not be reduced to any of the five models. Other recordings tending towards the accelerando model shape the sixth piece significantly shorter than the first, and thus carry the momentum of the accelerando into the final piece, especially Florent Boffard 2013 (24.620.0-21.4-7.7-6.6-19.7; 1:16-1:02-1:06-0:24-0:20-1:01; total 5:09). This tendency is also recognizable in Steuermann 1957a (25.7-18.1-15.5-7.5-11.7-21.5; 1:08-0:48-0:41-0:20-0:31-0:57; total 4:25). Glenn Gould 1965, in contrast, occupies rather an intermediate position between the accelerando and frame models (26.6-19.9-15.3-5.9-8.0-24.3; 1:23-1:02-0:48-0:18-0:25-1:16; total 5:13). The graph of relative tempo (Example 11, lower diagram) makes Gould's unorthodox tempo-shaping particularly clear, above all in pieces 1-4 (see section 4 ).

[3.14] In synopsis, the typological character of these models must again be emphasized - they should in no way be misunderstood as aesthetic criteria for the evaluation of performances. The recordings that conform particularly strongly to any one of these models might well distinguish themselves by certain details, perhaps eccentricities, which surely does not preclude that they plausibly unveil layers of meaning in the work. We would also like to point again to the relationship between the models and the absolute tempo. On the one hand, most models are less able to take a distinctive shape in the fast basic tempi of the earlier recordings than in slower recordings, which allow a greater variance in the tempo and duration. On the other hand, some models correlate closely to the choice of absolute tempi. In this way, it can be established that a clear expression of the frame model requires a slower tempo, so that the framing pieces can be sufficiently weighted. Among representatives of the opening model in contrast, a cluster of generally faster recordings is found (Kraus 1960, Zykan 1970, Dünki 2005), while conversely in the finale model a cluster of especially slow approaches can be observed (Uchida 2000, Eschenbach 2000). Of course, these are merely general tendencies and do not preclude alternative tempo conceptions. In fact, some of the most striking tempo conceptions have yet to be mentioned. For example, the fastest of all considered recordings by Karl Steiner from 1962 cannot be adequately described by any of the presented models. The percent values in Steiner are consistently so close to the average that they reveal no specific emphasis, with the exception of a slight displacement from the framing pieces to the middle pieces $(23.0 / 24.5 ; 19.9 / 17.3 ; 19.1 / 18.9 ; 7.7 / 6.8 ; 9.6 / 9.2 ; 20.7 / 23.3)$. This recording thus shows itself to be an extremely fast variant of a standard dramaturgy formed across decades, falling under the mean duration values with a clear consistency $(0: 55 / 1: 16$; 0:47/0:54; 0:45/0:59; 0:18/0:21; 0:23/0:29; 0:49/1:14; total 3:58/5:13).

[3.15] The largely fast tempi of the recordings before 1970 speak, on the one hand, for an antiromanticizing tendency, which must also be recognized as one facet of a specific Schoenbergian performance tradition. On the other hand, the fast tempi can be understood as an indication that the sixth piece in these performances is usually understood not extraterritorially, but rather as the conclusion of a synoptic six-part formal progression made cohesive by the fast tempo-a "classicist" tendency that can be demonstrated in many details of some of these early recordings, including Steuermann's. At the same time, the fast basic tempo prevents the "didactic" demonstration of structural details that is characteristic of many later recordings. At this point, microformal aspects of interpretation must thus be included more prominently in our discussion.

\section{Steuermann's Interpretations of the Piano Pieces, op. 19, in the Context of the History of Schoenberg Performance}

[4.1] The following micro-analysis of the six individual pieces proceeds from Steuermann's last recording in 1963, contrasting Steuermann's interpretation with 40 other recordings of the cycle 
from between 1925 and 2018 (see Example 2 above). In the present section, we consider each piece separately. We then conclude with a comparative discussion of Steuermann's overall conception of the cycle in its historical context in section 5. Structural-analytical considerations in reference to the six pieces can be followed with the aid of the annotated score. ${ }^{(41)}$

\section{No. 1, Leicht, zart $\left({ }^{`}\right)$}

[4.2] In no. 1, the functional components of a sonata form are recognizable in outline (see the annotated score, pp. 1-3). The "exposition" with two clearly contrasting "themes" (mm. 0.6-4.3; mm. 7.1-8.2), connected by a transition (mm. 4.5-6.3), is followed without a break by a "development," which is reduced to a tremolo and motivic remembrances (mm. 8.2-12). ${ }^{(42)} \mathrm{A}$ caesura-forming fermata (m. 12.1) and silence (m. 12.2) then lead to a "recapitulation" (mm. 13-17). The recapitulation, at first not motivically recognizable as such, becomes clear in the second measure (m. 14), which in its return to a ${ }_{8}^{6}$-rhythm takes up the gestural material of the first two measures. As the pitch analysis in the annotated score shows, the same layering of thirds underlies m. 1 and m. 13. In his letter to Gielen, Steuermann refers indirectly to the recapitulatory function of this measure: "The melody in bar 13 should be somehow the same voice which started in the beginning" (1942). Of course, at the same time, the espressivo character of the "transition" from m. 4.5 is continued here, signaled not least by the full "quartet voicing."

[4.3] For this first piece, Steuermann, in his letter to Gielen, suggests the relatively fast tempo of $\downarrow=$ 100 (see Example 2 above). He approximates this tempo in the live recordings from 1954 (97.1) and 1962 (97.2), and a "forward-pressing" strategy is also evident in the live recording 1957b (94.7). ${ }^{(43)}$ What Adorno ([1964] 1982, 313-15) referred to as Steuermann's high-risk playing style is clearly audible here. Because of the strong continuity throughout his six recordings, ${ }^{(44)}$ comparing mean values from 40 other recordings with an "abstracted" Steuermann interpretation averaged across his six recordings can help to reveal what is specific to his approach. The following discussions of each piece will therefore always take their cue from diagrams with two curves, comparing the mean tempo values across the six Steuermann and 40 other recordings (Example 12).

[4.4] The phrase structure of the piece is already compositionally clearly marked by a number of factors, including silences (mm. 2.1, 4.4, 12.2), phrasing slurs and/or reduced density of movement (mm. 3.3 5.4), as well as modifications of tempo at three places, amounting to a compositional elaboration of phrase arching ${ }^{(45)}$ - that is, a sequence of tempo-dynamic arches (especially evident in mm. 2, 11, 13, 14). Steuermann's tempo-curve shows on the whole a somewhat steeper progression than the average of the compared recordings (Example 12: mm. 1.3-1.4, 2.2-2.6, 6.2-6.3, 10.1-10.4, 14.6-15.4), a sign of deliberately shaping the phrasing through rubato, through "half and quarter cadences" (1942), which should make the musical units comprehensible to the listener. At times however, a path markedly narrower than the average of the other recordings is evident (mm. 10.415.1), which can be understood as evidence of an effort to maintain the main tempo in the course of the transition from the development to the recapitulation. The composed-out phrasing rubato of the first two bars in the slur placement, silence (m. 2.1), tempo, and dynamic markings (m. 2: "etwas zögernd"; hairpin to m. 2.4), (46) is realized by Steuermann not only through a reduction in tempo in the second half of each measure, as in the other recordings, but also through an accelerando in the first half. Similarly, all of the Steuermann recordings make the silence in m. 4.4 very clear. The following (fourth) phrase is outlined by a wavelike accelerando up to the beginning of m. 6, followed by an extreme slowdown. This slowdown, to less than half of the main tempo (mean value 41.6) in mm. 6.2-6.3 is explained, on the one hand, by a large-scale formal caesura and, on the other hand, by the desire to realize the complex polyphonic articulation in this passage (legato and staccato at the same time in the right hand). (This is realized particularly impressively in the studio recording from 1963; see Laubhold 2018, 81).

[4.5] The abrupt speedup in the seventh measure is similarly above average. The contrasting effect of the dotted rhythm introduced here is reinforced by the higher tempo-plateau, which is largely maintained until the end of m. 10, although the two thirty-second note figures marked "flüchtig" also show a clear increase in tempo; especially the second of these figures is significantly faster in Steuermann than in the average of the 40 other recordings. 
[4.6] The crescendo in $\mathrm{m} .9$ in the left hand remains unrealized in all six Steuermann recordings. Rather the pianissimo is held, probably so as not to cover the melodic line A3-G3 in the crossing right hand, although only in the studio recording from 1963 is the G3 played more loudly than the $\mathrm{A} 3$, suggesting a crescendo at least in the melodic line. In the following "discharging" motion (mm. 11-12), Steuermann again departs markedly from the mean value of the other recordings, doubtless with the intention of preempting the danger of a "disruption" of the piece, referred to in his letter to Gielen, that would arise through "tempo cadences" that were too frequent or too strong (1942). This particularly suggests that the reason for the tempo reduction in m. 6 may well be less the intention to produce a large-scale formal caesura than a technically contingent fine-tuning. In the same way, the acceleration in mm. 15.4-16.2, massive compared to those of the other recordings, can be explained technically by the desire not to let the high chord E5-G\#5-D\#6 fade entirely, so that the change to its chromatic neighbor chord in $\mathrm{m} .17 .5$ can be followed by the ear (Laubhold 2018, 76-77). (Only in the recordings from 1954 and 1963 can this actually be heard, as a result of a particularly drastic increase in tempo.)

[4.7] A relationship between these details and the larger form is first established by Steuermann's tripartite shaping of the tempo, with a strong acceleration in mm. 7-10 (clearly evident in Example 12) and his return to the starting tempo in $\mathrm{m}$. 13, which conveys the sense of a recapitulation. ${ }^{(47)}$ Although the tempo does not remain steady neither at the beginning (due to the fragmentation of the phrases and the many tempo modifications such as "etwas zögernd" in m. 2) nor in the "recapitulation" (m. 14 already contains a "molto rit.," though this can be understood as analogous to $\mathrm{m} .2$ ), the correspondence between Steuermann's chosen tempo-regions is nonetheless striking in comparison with the middle section. This is especially remarkable when compared with the other recordings, as Example 13 demonstrates. A slow-fast-slow dramaturgy can be found in many but far from all recordings; it is particularly clear in Pollini 1974, Henck 1994, and Körber 2018. Compared to this, "unorthodox" recordings such as Gould 1965, Liubimov 1971, and Majlingová 1977 reveal significantly less defined architectonic conceptions, and in many cases (Gould is exemplary along these lines), no clear articulation of sections can be found at all.

[4.8] One can certainly ask whether an accelerando in the middle section is in keeping with the composed form, as in $\mathrm{mm} .7$ and 8 there is already a composed-out acceleration with respect to the preceding thematic ideas (the double-dotted rhythm $\$$. $\&$ can be understood as a diminution of the figure $\delta . \&$ in mm. 5 and 6). Here, Steuermann's effort is recognizable to return immediately to the region of the main tempo after such accelerandi, much in the sense of preserving a "unity of tempo" (see Example 12, mm. 7.2.2, 8.2-10.2), and thus to shape the accelerando exclusively as a formal marker of contrasting moments (contrasting theme in m. 7, "fleeting" ("flüchtig") figures in $\mathrm{mm} .8 .1$ and 10.1.2). One could certainly speak here of a functional shaping of the tempo.

[4.9] A more precise positioning of Steuermann's performance style in its historical context can be achieved on the basis of a quantitative correlation and factor analysis of the total 41 recordings, performed with help of the software SPSS. As for most mean values, of the six Steuermann recordings, only the studio recording from 1963 was included in this analysis, so as not to distort the resulting statistical values. The values on which this correlation and factor analysis are based are logarithmically scaled deviations of each individual tempo point from the respective main tempo value. This means that in this analysis, only the relative shaping of the tempo (rubato, phrasing) in the 41 recordings is captured. The absolute tempo values will then also be considered by means of comparative tempo graphs (see Example 16 below).

[4.10] Example 14 shows the correlation coefficients between Steuermann 1963 and the 40 other recordings. The higher the coefficient, the stronger the recording's correspondence with Steuermann's conception. Values above 0.8 indicate a significant degree of agreement. ${ }^{(48)}$ The mean values in the bottom row of the table show that significantly lower correlations are recorded for nos. 3 and 6, and thus that the individuality of Steuermann's approach is particularly evident in these two pieces.

[4.11] On the whole, it must be acknowledged that these coefficients offer only a very rough guideline in respect to the similarities or differences between the recordings. More precise points of reference are provided by the pattern matrix of the factor analysis, documented separately for each 
of the six pieces in Example 15. ${ }^{(49)}$ Here individual factors are identified that are characteristic for a portion of the recordings. The pattern matrix then shows to what extent the individual recordings conform to these factors. In each of the six pieces, there is a primary factor, which strongly characterizes the majority of the interpretations (one could perhaps venture the hypothesis that this primary factor is largely determined by the musical text-a strong external guideline that in a way molds all of the interpretations), as well as between one and three further factors, mostly applicable to only a smaller portion of the recordings. Correlation with the primary factor is particularly strong in the second piece, which is hardly surprising given the rigid ostinato tempo that both characterizes the entire piece and allows for only marginal deviations.

[4.12] Example 15 serves as the basis of comparative tempo graphs for each of the six pieces in this section, with Example 16 showing the graph for no. 1. These graphs document, in addition to Steuermann's 1963 studio recording and the mean values of the 40 compared recordings, four individual recordings, each of which either correlates clearly to one of the factors or cannot be precisely classified. The following colors are used: light blue = Steuermann 1963; black dashed line $=$ average across the 40 compared recordings; green $=$ factor 1 ; orange $=$ factor 2 ; red $=$ factor 3 ; gray or gray dashed line $=$ factor 4 or unclear classification. Example 16 shows the six curves for the first piece. Steuermann's interpretation fluctuates here between factors 1 and 2 (see Example 15). The interpretation that most closely correlates with the primary factor, Henck 1994, movesunsurprisingly -in strong synchrony with the average values within a narrow frame, yet not without significant departures: the less pronounced caesura before the transitional theme in $\mathrm{m}$. 4.5, the tightening of the tempo after the "flüchtig" figure at the end of $\mathrm{m} .10$ before the ritardando in $\mathrm{m} .11$, and above all the strong reduction in tempo in the concluding section and corresponding slip in the main tempo (Example 16). Inverse to this is Majlingová 1977, where the extreme swings in the tempo curve in the first section imply a character of "losing oneself," a world away from Steuermann's phrase-oriented interpretation. The particularly strong correlation between Steuermann's and Pollini's recordings suggested by Example 14 is understandable, notwithstanding Pollini's narrower adherence to the main tempo in $\mathrm{m} .2$ and in the "flüchtig" figures, compared to Steuermann.

[4.13] Else C. Kraus's 1960 recording is of particular interest. Kraus was a pianist Schoenberg highly valued and who, in addition to premiering the piano pieces op. 33a and 33b, also produced two complete recordings of Schoenberg's works for piano (see Kraus 1974). Her curve shows several significant differences from Steuermann's, the most important being a rather restrained tempo in the contrasting theme and a sharp tightening of the final phase of the piece. Her extreme vacillations at the beginning are less concisely aligned to the phrase structure than are

Steuermann's, and neither the ritardando in $\mathrm{m}$. 1.4 nor the abrupt accelerandi in $\mathrm{mm} .3 .1$ and 6.1 can be understood as phrasing rubato in a structural sense. Although not to such an extreme extent as that of Majlingová, Kraus's interpretation can be seen as a document of a more irrational and spontaneous shaping of the rubato, considerably less text-oriented than Steuermann's.

\section{No. 2, Langsam $(\bullet)$}

[4.14] The second piece can be understood as a clear contrast to the fluctuating tempo conception and the structural complexity of the first, due to its rhythmic ostinato, its outright simplicity, and its clearer allusions to triadic harmony, which here is deliberately deconstructed into atonality (see the annotated score, pp. 4-5). This is surely one reason why so many analyses have been dedicated to this piece. ${ }^{(50)}$ From a pianistic approach, a doubtlessly crucial challenge lies in bringing out the opposition between the ostinato thirds, which are to be played "äußerst kurz" (extremely short) and "gut im Takt" (strictly in time), and the expressive thematic gestures in m. 3 (with upbeat) and m. 6. Particularly interesting is that these two layers do not remain uninfluenced by one another, but rather the articulation and rhythmic regularity of the ostinato is affected by the expressive figures, so that in $\mathrm{mm} .4$ and 5 the appoggiatura-like emphasis of the figure from $\mathrm{m}$. 3 penetrates into the ostinato (in the form of the tenuto eighth note C5-Eb5). Chords and chordal combinations based on major and minor thirds (sometimes referred to as "gamma harmonies"; see Ernő 1971, 35-66) - for example B-D-D\#-F\# in $\mathrm{m}$. 3 with upbeat, or G-Bb-Bł-D in the final chord, both of which belong to set class [0347] - and related ambiguous harmonies continually lead to new colorations of 
the ostinato third G4-B4. Formally, the piece is characterized by a question and answer pattern of the contrasting (and directionally opposite) melodic gestures of $\mathrm{mm} .3$ and 6, while $\mathrm{mm} .1-2$ can be understood as an introduction and $\mathrm{mm}$. 7-9 as an epilogue to this thematic dialogue, and $\mathrm{mm}$. 4-5 as a double echo of the first figure. Furthermore, a variation of a lamento topos connects mm. 5-9 (partly chromatically descending progression from G-B to C-E).

[4.15] The six Steuermann recordings again remain relatively constant in terms of tempo and only marginally faster than the average (mean for Steuermann $=49.5 \mathrm{bpm}$; mean for the other 40 recordings $=47.2 \mathrm{bpm}$; see Example 2 above). The clearer staccato articulation of the 1963 studio recording when compared to the earlier recordings may be the result of gained studio experience; in the live recording the staccato comes across less pronounced, perhaps in order to allow the ostinato to project in the concert hall.

[4.16] A particularly conspicuous departure from the score is Steuermann's accent on the high third B5-D6 in the upbeat to m. 3, mentioned also in his letter to Gielen ("I don't mind to 'connect' the melody tones by a fresher impuls[e] in the first tones, but I am often criticized for such things"; 1942). Indeed, in all six of the recordings both of the eighth notes in this upbeat are strongly emphasized, although the accentuation of the high third is much more prominent and doubtless employed by Steuermann as a deliberate moment of surprise, an interpretation not totally at odds with Schoenberg's $m f$, although Steuermann plays more of a decrescendo than a crescendo between the two eighths. Schoenberg had in fact wrestled with the nuancing of the dynamics at just this spot; a lengthy note on the realization of the dynamics and accents was planned in the autograph fair copy of this piece, but ultimately not included in the printed version:

$>$ or sf always indicates only a small emphasis, adjusted to the context. This emphasis may be stronger than the emphasis the beat in question would receive naturally, but must be differentiated from spots marked $m f p, f p, m f p p$, fpp, or even $f f p p$, where individual notes should really stick out from their surroundings due to their intensity and then immediately return to as before, perhaps through immediate muting. ${ }^{(51)}$

Undoubtedly, this note refers particularly to the interposed arpeggiated chord in the high register at the beginning of m. 5 (highest note Fb6), which forms, with the high third (Bq5-D6) in the upbeat to $\mathrm{m} .3$ and the final chord (highest note D6), a macroformal neighbor tone across the entire piece (D6-Fb6-D6). Schoenberg changed the duration of this chord in the autograph fair copy from an eighth to a sixteenth; at the same time, the accent present in the first autograph in the right hand is missing in the fair copy (the accent in the "appoggiatura" figure in the left hand, however, is retained). It is possible that Schoenberg was concerned that this chord could be articulated too sharply; nonetheless the accent was eventually included in the printed version. ${ }^{(52)}$ The planned instruction, however, could also indirectly refer to the upbeat to $\mathrm{m}$. 3, specifically to the relationship between the $m f$ with crescendo and the $p$ in the following measure. Steuermann's efforts to establish this $p$ immediately are particularly successful in the recording from 1963. And although he plays the chord in $\mathrm{m} .5 .1$ very restrainedly, the necessary shortness (sixteenth note) and the staccato of the immediately following third $\mathrm{F} \# 3-\mathrm{A} \# 3$ is not consequently realized, as the chord from $\mathrm{m} .5 .1$ continues to sound in the pedal (except in the recording from 1949). This lets the continuity between the thirds $\mathrm{Gb} 5-\mathrm{B} b 5$ (m. 5.1) and F\#3-A $\# 3$ (m. 5.2), a secondary structural layer, emerge more clearly. Steuermann's decisions against the text can arguably be understood as a conscious "reading between the lines," which aims to bring hidden layers of meaning in the music to the surface. ${ }^{(53)}$

[4.17] As indicated before, the differences between the interpretations tend to be slightest in this piece, due to the clear tempo framework produced by the ostinato. Nonetheless, Example 17 shows a few interesting differences in the details. For the first thematic figure, for example, the low point of the tempo curve of the 40 other recordings falls in m. 3.1 and not, as in Steuermann, in m. 2.4; the extreme elongation of the upbeat eighth note is thus tendentially replaced by a tenuto on the arrival note $\mathrm{D} \# 4$ in $\mathrm{m}$. 3 by most performers, while Steuermann plays this note "a tempo." The expressive stretching of this first thematic figure in the middle of m. 3 is also much stronger in the majority of the compared recordings than in Steuermann's; he foregrounds the regularity of the ostinato, which continues in parallel. Also conspicuous in comparison to the other recordings is 
Steuermann's broadening of mm. 5.1-5.2 (contributing to his "reading between the lines" at this point) and his efforts, at least suggested, to take the beginning of the answering figure (m. 6) close to the main tempo. The other recordings generally proceed here on a lower tempo plateau.

[4.18] Striking differences can be found in the absolute tempi of several of the recordings (Example 18); the maximum tempo of $84.0 \mathrm{bpm}$ is found in Majlingová 1977, contrasting with her extremely slow beginning of no. 1. At the opposite end of the spectrum, Christoph Eschenbach 2000 reduces the tempo to a near stasis at $29.7 \mathrm{bpm}$ (almost a third of the maximum value), here part of a generally broad interpretation of all six pieces (see [3.1] and [3.10] above). The factor analysis (Example 15) confirms that, despite the discussed peculiarities, Steuermann's tempo conception is largely representative of a general trend. This is also evidenced by the many correlation values above 0.8 (Example 14) as well as the close correlation between the tempo curves of Steuermann 1963 and Beveridge Webster 1967 (Example 18); in the factor analysis, Webster's interpretation shows the strongest correlation with the primary factor (Example 15). The curves in Example 18 reveal the differences of those recordings that are significantly less consistent with the primary factor.

[4.19] The deciding factor in this rhythmically regular piece proves to be the choice of absolute tempo, which after no. 6 varies the most (relative standard deviation of the 40 recordings $=24.8 \%$; no. $6=25.0 \%$; see Example 2) and renders very different facets of this enigmatic work audible: while the faster interpretations make the correspondence of the thematic figures plausible in the sense of a question and answer, the slower interpretations dwell in the details of the ambiguous harmonic-melodic formations and their unpredictability. Steuermann's interpretation assumes a middle position, in which both of these aspects coexist. The possibility of nuanced shadings is shown, for example, by his realization of the arrival chord in m. 6.3, whose dissonant effect is brought out in the recordings from 1954 and 1963 by the strong presence of the lower notes of the chord. In the other recordings, the melodic link between the D4 in the upper voice and the preceding melodic line stands in the foreground, so that the chord seems to be more a coloring of the melodic element.

\section{No. 3, Sehr langsame .}

[4.20] The third piece is connected to the second firstly by the gradated tempo markings (Langsam

-Sehr langsame •), especially when the contrasting tempo of the following no. 4 is considered. Yet it also contrasts with no. 2 in its full piano writing, which can easily be associated with Brahms. From a formal view, two aspects must be emphasized (see the annotated score, pp. 6-7). On the one hand, it is possible that the piece should be understood as a single theme type of the category "sentence": a presentation phrase with a compound (or repeated) basic idea (mm. 1-4), ${ }^{(54)}$ a continuation phrase with fragmentation of the material of the basic idea (mm. 5-7), and a cadence (mm. 8-9), in which elements of the tonal structure of the basic idea are retained (especially the ambiguity between the possible tonal centers Eb major, G minor, and D minor). On the other hand, the form has a clear two-part structure (which does not fundamentally contradict the first interpretation): the silence at the beginning of $\mathrm{m} .5$ interrupts the thick texture of the first four measures and is followed by an increasingly thin texture with a tendency toward the isolation of the melodic voice (mm. 6.2-6.4, 7.2-8.3) and calming of the rhythm. The polyphonic and polytonal layering of the first four measures, clarified by the combination of the dynamics $f$ (right hand) and $p p$ (left hand), is thus relinquished.

[4.21] Steuermann's recordings stand out due to absolute tempi far above the average and thus short durations. The studio recording 1957a is actually shorter than the shortest of the 40 compared recordings (0:41/0:42), and Steuermann's other recordings are close or identical to this minimum value (0:42-0:48). As we have shown in a parallel study (see Utz and Glaser 2020, 194-95), this short duration of no. 3 is generally characteristic of early recordings. In this piece however, the main tempo and duration alone are insufficient to grasp the formal conception of each pianist, as will be shown in the following discussion. 
[4.22] The average tempo curve (Example 19) shows a higher tempo plateau for mm. 5.2-7.3 in Steuermann's recordings. This conception is shared by approximately half of the compared recordings (19 of 40); in these recordings, the average tempo of mm. 5.2-7.3 is more than $3.0 \mathrm{bpm}$ faster than the average tempo of mm. 1-4 (maxima in Kraus 1960 with a difference of $14.5 \mathrm{bpm}$ and Russel Sherman 1999 at $13.9 \mathrm{bpm}$ ). The opposing conception of a noticeable slowing of the second part is much rarer: an extreme example is Gould 1965 (-22.6 bpm), and less extreme are Serkin 2009 (-7.7 bpm) and Vintschger 1970 (-6.2 bpm).

[4.23] The six Steuermann recordings show their usual constancy in the shaping of the phrases. Their most conspicuous characteristic is the tempo caesura at the end of $\mathrm{m}$. 2, which is much more prominent than in the 40 compared recordings (Example 19). Steuermann thus accentuates the two-part structure of this "compound basic idea," allowing him to differentiate the dynamics correspondingly: the dynamic highpoint within the $p p$ of the left hand in $\mathrm{m} .3 .1$ must be on a perceptibly quieter level than the surrounding chords of the right hand in mm. 2.4 and 3.2 for the polyphonic layering to come across clearly. This becomes even clearer with Steuermann's accentuation of the chords in the right hand-analogous to the prominently emphasized beginning of the theme in no. 2 (upbeat to m. 3): the first downbeat chord is forcefully marked in all six recordings and then on the second beat held back, once more against Schoenberg's written dynamics (crescendo from m. 1.1 to m. 1.2). Especially in the recording 1957a, an important modification is the absence of a caesura in m. 4 (on the other hand, the suspension-like resolution $\mathrm{C}-\mathrm{Bb}$ in the left hand is broadened, especially in 1949; Example 19 shows this also to be a characteristic, if less distinctively, of the 40 compared recordings). The two parts of the piece are thus brought together in one "arc," and the interpretation as a coherent "theme" becomes audibly plausible-especially due to the brisk tempo. In the second half of Steuermann's interpretation, compressions result particularly from a shortening of the two held notes Eb4 in m. 6.2 (half note) and m. 7.2 (dotted quarter note). These features cannot be found in the curve of the other 40 recordings shown in Example 19 and can thus be considered further evidence of Steuermann's sustained efforts to render the course of the piece in a single, synoptic motion. Overall, however, a strong correlation between Steuermann's curve and the averages of the compared recordings is clear.

[4.24] The factor analysis also shows this model character of Steuermann's interpretation, which reaches a high value for the primary factor (Example 15). The factors are however markedly more divergent than in no. 2 , as the significantly lower correlation coefficients show (mean value $=0.472$, in contrast to 0.756 in no. 2; see Example 14). The comparative tempo diagram (Example 20) shows a certain correlation between the curves of Steuermann and Liubimov 1971 (the two recordings correspond in the high value of the primary factor and beyond this in a similar value for factor 4 ) with the exception that Liubimov does not shorten the held Ebs in mm. 6 and 7. Factor 3, introduced by Pollini 1974, could be explained by an alternative phrasing of the basic idea contrary to the primary factor, recognizable in a certain negative correlation to Liubimov 1971 and Steuermann 1963. ${ }^{(55)}$ Gould's eccentric interpretation of no. 3, which we discuss in detail elsewhere (Utz and Glaser 2020, 194-96), can be seen in every way as the antithesis of Steuermann's. Gould hardly subdivides the idea in $\mathrm{mm}$. 1-4, instead leading it through a sort of continuous ritardando from an extremely fast beginning (the peak in $\mathrm{m}$. 1.4 is $88.9 \mathrm{bpm}$, the low point in $\mathrm{m}$. 4.4 at 34.4 $\mathrm{bpm}$ ) to a very held back and thus strongly contrasting second part (also here with extreme fluctuations between 61.2 and $28.1 \mathrm{bpm}$ ). That factor 2 is dependent above all on such tempo contrasts between the two parts is reflected in the high values for comparable conceptions such as Serkin 2009 or Vintschger 1970 and in the high negative values (Barenboim 1994, Kraus 1960, Sherman 1999, Wyttenbach 1989) for contrary conceptions (slow first part, fast second part). Eschenbach's factor 4 could be connected above all with the stately absolute tempo $(28.1 \mathrm{bpm})$, which is brought to a virtual standstill in $\mathrm{m} .4(\mathrm{~m} .4 .1: 18.3 \mathrm{bpm})$, and additionally tends to a "spelling out" of melodic tones, a decision that, especially in the second part, leads to a leveled curve. In the process, minute differentiations in the articulation come into their own-for example, in the upbeat to m. 8, where the series tenuto-ordinario-staccato under a legato-slur is particularly elegantly shaped by Eschenbach. Pollini also realizes this detail very convincingly, though he minimizes the caesura, in a manner reminiscent of Steuermann, who consistently passes over this 
phrasing and takes mm. 7 and 8 in a single arc (followed here by Gould 1965) - also evidence of Steuermann's synoptic tendency in this piece.

[4.25] Steuermann's consistently realized correspondence between pieces 2 and 3-in view of the fast tempi for both pieces, followed by more moderate tempi in nos. 4 and 5 -has consequences for the overarching formal conception. Since the musical ideas in both pieces appear as theme types (no. 2: question and answer; no. 3: sentence), they become intuitively understandable as elements of an overarching context, to which the clear three-part form of the protean first piece also contributes. In addition to such thematic correspondences, which tend to be supported by faster tempi, the form-shaping element of contrast is also present in Steuermann, especially in his interpretation of no. 4 .

\section{No. 4, Rasch, aber leicht $(\bullet)$}

[4.26] This shortest of the six pieces forms in many respects a central marker of the cyclical form (see [2.7] and the annotated score, pp. 8-9). It contrasts particularly starkly with the preceding piece, no. 3, in tempo and character, and it is not, unlike the five other pieces, connected to the preceding or following piece by neighbor note relationships between the final and beginning harmonies. Furthermore, the monophony and high register of its beginning represent a clear contrast to what came before. The scherzando character of the piece establishes itself in the doubledotted rhythm of m. 1 (referring back to the "secondary theme" of no. 1), the staccato articulation in $\mathrm{mm}$. 3-4 (heightened to martellato in $\mathrm{m} .10$ ), and the unexpected grace notes, twists, and stops (in mm. 4-5 and 8-9, the development seems to spin off into nothingness, both times initiated by a "poco rit."). (56) A relationship in the pitch structure of $\mathrm{mm}$. 10-13 and $\mathrm{mm}$. 1-5 has been frequently noted (see especially Morris 1993), and a structural recapitulation in the pitches can been uncovered here as in no. 1 under the differing musical surfaces. The tripartite form is also reinforced by the contrasting gentler (trio) theme in $\mathrm{mm}$. 6-9 (with upbeat), which is nonetheless related to the outer parts - for example, in the grace note on $\mathrm{m} .6 .1$, which corresponds to the "harpsichord accents" before m. 2.2 and after m. 8.2 (Fearn 2002, 278). The final consequence of these grace-note-like accents is the striking final cadence, which seems to settle what had been left open in mm. 5 and 9. Yet the "openness" of the tonal configuration of this ending, despite the leading-tone-like $B b 3$ [A $\$ 3]-B \nmid 3$ (mm. 12-13), provides a connection to no. 5: here, the beginning F major melodic gesture in the right hand corresponds to the beginning notes of no. 4 (mm. 1-2; see also mm. 10-11), so that the tritone B-F, much in accordance with a basic principle of early atonal harmony, manifests a dominant function - or at least a particularly close pitch relationship (this tritone also forms the upper segment of the penultimate accord, m. 12.2).

[4.27] Steuermann's performances first and foremost emphasize the first caesura with fermata in m. 5.1 much more clearly than the compared recordings. Example 21 indicates that in contrast to the "poco rit." realized by Steuermann in m. 7, an increase in tempo can actually be measured in the compared recordings. The remainder of the compared recordings proceeds analogously to Steuermann, including a shortening of the quarter rest in m. 9.2. Striking in Steuermann's is the tendency to return to the main tempo in $\mathrm{m} .6$, while the average of the other recordings remains at a lower tempo plateau. The increase in tempo during the cadence, which intensifies the composed accelerando in $\mathrm{m} .10$, and particularly the abbreviation (near deletion) of the eighth rest in $\mathrm{m} .11 .2$, is also more pronounced in Steuermann's performance than in the compared recordings, strengthening the "clean sweep" character of this ending. At the same time, Steuermann's tempi are significantly above the mean for the compared recordings (106.0/93.9), although the studio recording 1957a distinguishes itself with a more restrained tempo (96.3). On the whole, Steuermann offers an end-oriented interpretation achieved by a separation of the first phrase (mm. 1-5) and a synoptic tendency during the remainder of the piece, compressing the tempo up until the end.

[4.28] The factor analysis here again shows a relatively strong role of the primary factor in Steuermann 1963; his curve thus correlates not only with the mean values, but also closely with Eschenbach 2000, where the strongest manifestation of the primary factor is found (Example 22). Eschenbach operates at a lower tempo plateau (81.8, compared to 102.7 in Steuermann 1963) but is 
also inclined to a clear caesura in mm. 4-5 and a more strongly linear, end-oriented shaping throughout. Factor 2, somewhat pronounced in Markus Groh 2002, is characterized by a slight reduction in the fluctuation of the tempo (the relative standard deviation for Groh 2002 is 17.1/33,7, compared to Steuermann 1963 at 20.7 and Kraus 1960 at 35.1). The significantly minimized tempo reductions in mm. 4-5 and 8-9 lead to a total duration of Groh's recording three seconds shorter than in Steuermann despite the same main tempo (0:16/0:19). Striking in Groh's performance, compared to Steuermann's, is the time he takes in the silences in mm. 9.2 and 11.2, which strengthens the emphasis of the final cadence.

[4.29] Factor 3, pronounced in Majlingová 1977, is likely manifested in a two-part conception of the tempo shaping - analogous to that discussed in no. 3. Although she begins with a tempo close to the mean (ca. $100 \mathrm{bpm}$ ), she decelerates abruptly before m. 4 and resettles the following development at nearly half the original tempo (ca. $55 \mathrm{bpm}$ ), which she only marginally raises in the final cadence. Here is thus the exact opposite model to Steuermann's end-orientation.

\section{No. 5, Etwas rasch (•)}

[4.30] The fifth piece relates to the fourth like the third to the second - as a gradation of the tempo that forms a related but distinct character (see [2.6] and the annotated score, pp. 10-11). The underlying topos here is the waltz, although various metrical "disturbances" and ambiguities establish relationships to the scherzando character of no. 4 and also no. 1 -for example, in the suggestion of a siciliano rhythm in $\mathrm{mm}$. 7-8 (as well as in the relationship between the respective ${ }_{8}^{3}$ and ${ }_{8}^{6}$ meters and the eighth note pulse). Such relationships, as well as the striking final cadence, which spans four measures and extends conclusively across a wide register, may suggest that this piece could have been originally conceived as a final piece, especially considering, as mentioned above, that no. 6 was written only about four months after the first five pieces, which were written down in a single day. Formally, no. 5 is more complex and seems to have been conceived less architectonically (as was no. 4) than processually. A subject head is not followed by a proper continuation or answer; rather, the motion halts in the sustained tones of mm. 4-6, and the "attempt" at a cadence by means of the siciliano rhythm in mm. 7-8 comes to an abrupt end (m. 8.2), which in its five-voiced quintal chord also proves to be a kind of harmonic dead end ( $F \# 2$ C3-G3-D4-A4). The melodic motion resumes again in $\mathrm{m} .9$ and above all in $\mathrm{m}$. 10, reminiscent of the beginning (as if driven by the staccato sixteenth notes in the left hand) and is then interrupted again by the silence in $\mathrm{m}$. 12.1. The falling cadence, which begins with a sudden forte and change in register, concentrates the principle of layered thirds from no. 2 into a veritable tower of sonorities, leading to two chromatically linked final chords (with a certain polytonality of "tonic" and "dominant" in the final chord E-major 6/4 / B-major 9/7). Here too, the vagrant motivic outline, the frequent interruptions, and the abruptness of the phrases can be understood as manifestations of a scherzando or perhaps better, capriccio character.

[4.31] As in the other pieces, Steuermann establishes a clear orientation within this complex form by means of a particularly clear tempo cadence in m. 8.2 that is in the moment of the "broken off" siciliano cadence (Example 23). Here-analogously to m. 4 in no. 4 and m. 6 in no. 1 - the slowdown is certainly also explainable by a desire to precisely realize the complex polyphonic rhythms of the first part of the measure (tied sixteenth note with three following sixteenth notes distributed between both hands) including the following breath mark. Following this, as in no. 4, the caesuras (silences in mm. 10.1 and 12.1), on the contrary, are sharply shortened, and the musical progression thus coheres in a single, synoptic arc.

[4.32] While Steuermann's no. 3 is among the faster interpretations, the value measured for his main tempo in no. 5 is in a lower range: of the 40 compared recordings, only five have values below Steuermann's $111.1 \mathrm{bpm}$. While this leads undoubtedly to a specific dramaturgy that allows no. 5 more space and thus establishes a first element of closure, it contradicts Steuermann's suggestion in his letter to Gielen of $144 \mathrm{bpm}$, which corresponds almost exactly to the mean value of the 40 compared recordings (142.4 bpm). This can be explained through closer examination of the tempo curves of Steuermann's interpretations (Example 23): if only the first two measures are considered, the resulting values come close to or exceed the tempo given in the letter: 144.6 (1949), 138.7 (1954), 
146.3 (1957a), 165.2 (1957b), 179.1 (1962), and 154.0 (1963). ${ }^{\text {(57) }}$ Steuermann thus shapes the beginning, as Example 23 shows, in strong analogy to the compared recordings, although with less of a "build up" at the start (i.e., the tempo is established from the onset). Then, however, with strong slowdowns in mm. 3 and 4, Steuermann establishes a new halting tempo, which one can understand as an imaginative realization of the thematic "faltering" in this passage. Finally, with the metrical irritation caused by the siciliano rhythm, the tempo loses all momentum, and the motion comes entirely to a halt at an average tempo of $42.7 \mathrm{bpm}(\mathrm{m}$. 8.2). The following passage (mm. 9-11) then returns to the tempo plateau of mm. 5-6 (and not mm. 1-2), followed by the cadence's gradual reduction in tempo corresponding to the "poco a poco rit." (m. 12.2).

[4.33] A telling detail, found only in the studio recording from 1963, reinforces the effect of a macroformal closure in this piece: the final two chords are clearly separated from the preceding music by means of a particularly broad realization of the "molto rit." in m. 14 (recognizable in the "kink" at the end of the falling tempo curve; see Example 24 below). This dramaturgy, as one might expect, is manifestly different from the average of the compared recordings (Example 23). Here too, the caesura in $\mathrm{m} .8$ is the most pronounced, yet it is much less extreme than in Steuermann (m. $8.2=99.6 \mathrm{bpm}$, compared to a main tempo of 142.4) and is followed immediately by a return to the main tempo from m. 1. A close correlation between Steuermann 1963 and the values from the compared recordings can then be observed beginning in $\mathrm{mm}$. 10-11 up to the cadence.

[4.34] Again, the factor analysis allows a more nuanced picture, even if it does not adequately reflect the uniqueness of Steuermann's approach, since it assigns him a high value for the primary factor. Even so, the difference from Sanromá 1937, here the fastest of all the recordings (main tempo $=229.6 \mathrm{bpm}$ ) with the highest value for factor 2 , shows that most pianists tend to reduce the tempo slightly in $\mathrm{mm}$. 3-7. Sanromá, in contrast, after an already very fast start, raises the tempo in these measures even further (Example 24). His interpretation is similarly antithetical in m. 8.2, where he completely ignores the written breath mark and instead shapes beats 8.2 and 8.3 as a single event. And likewise, intelligible structures are hardly discernable within his breakneck cadence (including an accelerando even from mm. 13.3 to 14.1). Steuermann's negative correlation value for factor 2 shows the contrariness of his approach to Sanromá's.

[4.35] Thomas Larcher (1998) on the other hand, who reaches the highest value for the primary factor, shows a clear correlation with Steuermann's curve, although he preserves the tempo established at the beginning (120.2 bpm) with much greater stability. By contrast, Gould 1965 and Kraus 1960, here as before, serve as examples of interpretations not clearly attributable to any of the three factors. Analogously to Steuermann, Gould and Kraus slow down significantly in the second part, Gould here similarly to his interpretation of the third piece. In both cases, the extremely free shaping of the tempo lends the fifth piece less a capricious than an improvisatory, extemporary character. In Gould's recording, this is accompanied by a tendency towards a perhaps ironic internalization, apparent for instance at the beginning of the final cadence, where Gould plays a very restrained piano in place of the indicated forte. ${ }^{(58)}$

[4.36] The discussion of this piece shows perhaps most impressively Steuermann's medial position between a generation of performers, represented here by Sanromá and Kraus, for whom a free shaping of the tempo served as the basis of an inspired playing, and a younger generation, represented here by Larcher, for whom an orientation toward the score and the stabilization of a superordinate tempo are taken for granted. Equally clear in Steuermann are, on the one hand, the orientation towards the text and, on the other hand, a reading "between the lines" and the intention to apply the shaping of the tempo as a form-shaping force. It can hardly be disputed that an entirely individual and particularly comprehensible plasticity of the sounding process is achieved, and Steuermann thus impressively realizes the Schoenbergian ideal of a "graspable" musical form (see see section 5).

No. 6, Sehr langsam (•) 
[4.37] As suggested above, the last piece of the Six Little Piano Pieces may be understood as extraterritorial, due to the circumstances of its production (see see [2.5] and the annotated score, pp. 12-13). The intertextual references to the first movement and finale of Mahler's Ninth Symphony (1909) distinguish this sixth piece from the preceding five, connected with an autobiographical dimension with regard to the importance of Mahler for Schoenberg, the mention of the Ninth Symphony in the "Prager Rede" of 1912, and so on (Schoenberg [1912] 1975a, Schoenberg [1912/48] 1975b; Massow 1993).

[4.38] The compositional technique of the last piece is undoubtedly a strong contrast to the musical prose of nos. 1-5, in that it develops a "Klangfarbenmelodie" similar to Schoenberg's orchestral piece, op. 16, no. 3 (1909), by means of a constant re-illumination of the chords (Fearn 2002, 279, and Cramer 2002, 20-21). The piece ends in $\mathrm{m}$. 9 with the return of the two-layered six-voiced chord repeated twice at the beginning, followed by the falling ninth $\mathrm{B} b 2-\mathrm{A} b 1$ at quadruple piano in the low register, which can be understood as a reference to the final melodic gesture, $\mathrm{B} b 3-\mathrm{A} b 3$, in the violas at the end of Mahler's Ninth (the fact that $\mathrm{B} b$ and $\mathrm{A} b$ sound together here in the pedal again references, with respect to the $\mathrm{D} b$ major of Mahler's Adagio, a harmony combining the fifth and sixth scale degrees, and thus indirectly the famous final sonority of Das Lied von der Erde C-EG-A). The final (imaginary) added-sixth chord already occurs at the beginning (F\#-A-B conceived as the third, fifth, and sixth of an imaginary D-major chord, here alluding to the beginning of the first movement of Mahler's Ninth; see Massow 1993, 190) and is answered by a quartal chord that, also quasi autobiographically, refers back to the harmony of Schoenberg's Chamber Symphony, op. 9, from 1906 (this chord is elaborated into a slightly chromatically altered seven-voiced quintal chord in $\mathrm{mm} .5$ and 6 , that draws on $\mathrm{m} .8$ of no. 5). ${ }^{(59)}$ Despite the abstraction of the sounding material, one can distinguish a sort of reprise form, where the reprise and epilogue coincide in $\mathrm{m}$. 9. This is preceded by a development-like complication of the material in $\mathrm{mm}$. 5-8 with various inter- and intratextual allusions, and the interruption of the held chords by two silences (m. 7.1 and mm. 8.38.4) and an articulated recitativo, speech-like melody (mm. 7-8).

[4.39] As in no. 1, one can hardly speak of a main tempo here, but rather different temporal densities of a sequence of events. This of course can give rise to something like an imaginary pulse, which the calculated average tempo values may be understood to approximate $(\mathrm{m} .9$, dramatically slowed in nearly all the recordings, is excluded from the calculation of these values). Steuermann's absolute tempo values are very close to the average of the compared recordings (40.0/39.0; see Example 2), although the fluctuations reach maximal values both in his six interpretations (34.8$44.6 \mathrm{bpm}$, where the relative standard deviation $=9.5 \%)$ and in the compared recordings (18.6-62.1 bpm, where the relative standard deviation $=25.0 \%$; Example 2). Correspondingly, the mean correlation value is lowest for this piece (0.354; Example 14). The large divergences can also be seen clearly in Example 25. The absolute durations of Steuermann's recordings diverge more strongly than their similar main tempi might lead one to expect, between 0:57 in the recording 1957a and 1:17 in 1949 (Example 2).

[4.40] As a particular characteristic of Steuermann's interpretation, found to varying degrees in all six recordings, three factors are to be emphasized: (1) the clear tempo reduction in the realization of the high upper-neighbor figure D\#6-E6-D\#6 in quadruple piano (mm. 3.3-4.2), (2) the pronounced slowdown in m. 6 during the "resolution" of the suspension-like melodic gesture G\#3-F\#3, and (3) the acceleration of the motivic element in the "development" in $\mathrm{m} .7$ (this is presumably also an allusion to the end of Mahler's Ninth; see the annotated score, p. 13). (60) Ultimately, Steuermann's tendency to produce a two-part form through a large tempo cadence (here mm. 1-6/7-9) and to subsume especially the second part in a superordinate synoptic development, is recognizable here, as in the other pieces; this also explains the abbreviation of the silence in mm. 8.2-8.3. A comparison with the mean values of the other recordings (Example 25) highlights this specific dramaturgy in Steuermann's recordings. The return to the main tempo in m. 9, which Steuermann prescribed in his letter to Gielen, ${ }^{(61)}$ (analogously to the return of the beginning tempo in $\mathrm{m} .13$ of no. 1, see [4.7-4.8]), however, remains unrealized in all recordings. At most, an attempt at this is recognizable in the recording 1957a; with $37.6 \mathrm{bpm}$, however, the value of the beginning (47.6 bpm) here is still far from equaled. 
[4.41] The factor analysis hardly gives a unified picture, corresponding to strong overall divergences. In the comparative tempo graph (Example 26), alongside the four recordings chosen on the basis of the factor analysis, two additional recordings were included that illustrate the extreme spectrum of chosen absolute tempi: Mitsuko Uchida 2000, with a minimum tempo of 18.6 bpm, and Karl Steiner 1962 at $54.9 \mathrm{bpm}$, which is among the three fastest recordings. ${ }^{(62)}$ The difference in the corresponding durations is particularly spectacular, as it includes $\mathrm{m}$. 9, which was excluded from the calculation of the main tempi: 2:22 for Uchida 2000, and 0:49 for Steiner 1962. The final measure alone lasts 33 seconds in Uchida, and in Steiner, a mere 12 seconds. As stated earlier, Uchida's extremely contemplative and withdrawn interpretation puts the acoustic dimension of the piece on another plane, as if borne away from the previous music, evoking the extraterritorial character and the topos of memory.

[4.42] Herbert Henck 1994, who here too represents the primary factor, shows a tendency, visible to some extent also in the averaged curve, to understand the tempo of the piece in a type of long-term ongoing ritardando. This is made possible by a very high density of events at the beginning ( 53.5 $\mathrm{bpm})$. The following upper-neighbor figure is then already dramatically slower (35.9 bpm), and m. 6 drops further to $24.2 \mathrm{bpm}$. Unlike in Steuermann, m. 7 does not accelerate, but on the contrary is even slower (19.6 bpm). Also, the shortening of the silence in m. 8, although present, is less strongly pronounced. Different from Henck, Pi-hsien Chen 1996 and Steiner 1962, who share with Steuermann a high value for factor 2, realize exactly this acceleration in the "development" comparable to Steuermann, Chen to an extreme extent (she jumps from $21.7 \mathrm{bpm}$ in $\mathrm{m} .6$ to double the tempo, $43.6 \mathrm{bpm}$ in $\mathrm{m}$. 7). Her extreme stretching of the appoggiatura figure in $\mathrm{m} .6$ is also particularly clear in the graph (see Example 26, the nadir in m. 6.1).

[4.43] Steuermann's interpretation of the sixth piece seen in this context is a thoroughly specific approach, which is reflected in the modes of shaping realized by many other performers. Yet as a whole, it remains unparalleled in the history of the work's performance. Even the recordings by Steiner and Chen, which have similar values to Steuermann in the factor analysis and whose (relative) shaping of the tempo correlates unambiguously with Steuermann's, produce an utterly different impression. This is above all due to the different choice of absolute tempo. Steiner's extraordinarily restless interpretation necessarily leads to a fleeting and, at times, almost careless sequence of events, particularly during the motivic elements of $\mathrm{mm} .7$ and 8 . A world away from this, Chen achieves a powerful calmness at the beginning that seems appropriate for the character of the piece; however her extreme stretching of $\mathrm{m} .6$ and stark abbreviation of $\mathrm{mm} .7$ and 8 then lead to the impression of a disconcerting contrast that boarders on incoherence. Steuermann, in contrast, finds a balance between a synoptic tempo conception, which renders the piece in its global coherence, and a nuanced shaping of the tempo in $\mathrm{mm} .6$ and 7-8, by which he sets a formal marker also rhetorically justified by the speech-like gesture of $\mathrm{mm}$. 7-8, without producing the effect of an "external object." His articulation of the chords, however, cannot be considered entirely successful, as the overly direct sound, which can also be observed in the case of the chords at the beginning of no. 3, cannot solely be attributed to the direct miking, at least in the studio recording from 1963. ${ }^{(63)}$ The chords in $\mathrm{mm} .2 .3$ and 5.3 are especially articulated in a way that is hardly consistent with the piece's character. ${ }^{(64)}$ It would therefore be misleading to present Steuermann's interpretation as an unreachable ideal; rather, this interpretation shows an inexhaustible wealth of dimensions and potentials, which are constantly transformed and updated in the course of the performance history.

\section{Conclusion: A Structuralist Performance Style?}

[5.1] How can the individuality of Steuermann's performances be understood in their historical context? Can a "Steuermann factor" be clearly distinguished from global tendencies in the majority of other available recordings, as has been done for the playing of Vladimir Horowitz, for example?

(65) Are there indications that Steuermann's performance aesthetic has "caught on" and been subsequently taken up and further developed by the majority or a specific group of pianists? And finally, where does Steuermann stand between the poles of "rhetorical" and "structuralist performance" (Cook 2013, 5 and 41-55), or between "espressivo" and "neo-objective interpretation" 
(Stenzl 1995, 687-92)? On the basis of the comparative investigations presented here, the most important characteristics of Steuermann's interpretation will once again be recapitulated for the discussion of these questions and illustrated in one final graph, which presents Steuermann's 1963 recording alongside four important compared recordings (Kraus 1960, Gould 1965, Pollini 1974, and Henck 1994) over the course of all six pieces (Example 27). ${ }^{(66)}$ The tempo graphs of all five interpretations represented in Example 27 can moreover be followed along with the full audio recordings in Video Examples 1-5.

[5.2] A decisive aspect of Steuermann's approach is that he, as so aptly described by Hermann Danuser, aims to capture "the musical progression of the pieces as a whole by means of a swift conception of the basic tempo" $(1997,159-60) .{ }^{(67)}$ A brisk tempo is admittedly a general characteristic of earlier recordings before 1970-this is evident not least in Kraus and Steiner, who were close to the Schoenberg School. And the focus of Schoenberg's criticism of the first performances of op. 19 on the excessive speed, and thus lack of attention to structural detail, is certainly not accidental (see [2.9])). Precisely this attention to detail, described by Adorno ([1964] 1982) and Laubhold (2018 as the defining characteristic of Steuermann's playing, combined with the brisk tempo, leads to a close relationship between part and whole, as was undoubtedly the pianist's goal. The balance struck between a strong emphasis on smaller units of meaning through (phrasing) rubato on the one hand, and the orientation towards the main tempo, on the other hand, is what allows an interplay of "rhetorical" and "structuralist" performance to take place, a balance claimed for the Schoenberg school by Rudolf Kolisch under the slogan “Wiener espressivo."(68)

[5.3] In any case, such an adherence to the main tempo, in the sense of a return to a tempo plateau established at the beginning of a piece, is by no means found in all of the six pieces of op. 19 in Steuermann's interpretations. In no. 5, for instance, we were able to observe a tendency towards an overarching rallentando, in agreement with Steuermann's statements in his letter to Gielen. Similarly, in no. 6 the intended return to the beginning tempo in the final measure was left unrealized in favor of a general fading away. The extent to which Steuermann's interpretation also follows intuitive impulses - thus very much in the sense of the Schoenberg school's performance aesthetic bringing "the hidden to light" (dem Verdeckten ans Licht zu helfen) (Adorno [1964] 1982, 315) - can be shown precisely in the case of the fifth piece, here in the realization of the compositional idea of an "attempted theme" that loses itself in repeated interruptions by means of an increasingly faltering and disintegrating tempo conception.

[5.4] Compared with the other recordings, however, a strategy unique to Steuermann proves to be particularly salient: the macroformal structuring of all six pieces by means of a single prominent tempo caesura in each piece. This can be clearly identified in each case: $\mathrm{m} .6$ in no. 1, m. 6.3 in no. 2, m. 4 in no. 3, m. 4 in no. 4, m. 8.2 in no. 5, and m. 6.1 in no. 6. Especially in nos. 1, 3, and 5, further significant form-shaping elements are put on a level with these macroformal incisions: in no. 1, the contrast of the "secondary theme" is underlined by the intensification of the tempo (m. 7); in no. 3, the shortening of the caesura in the large-scale form (m. 4) acts in favor of a single thematic "idea" encompassing the entire piece; and in no. 5, the rallentando dramaturgy just mentioned contributes to the impression of an overarching tempo dramaturgy. The comprehensibility produced by the interaction of these elements of shaping (and in this case further underpinned by the brevity of the pieces) for Schoenberg was a basic requirement of composition as well as performance: "every idea must be presented so that the listener's power of comprehension can follow it" (Schoenberg 1934/36, 55;(69) see also Feß 2018, 40). The Society for Private Musical Performances [Verein für musikalische Privataufführungen], in which Steuermann, as "Director of Performance" [Vortragsmeister], played a leading role, made accordingly high demands on the "clarity, sound, and plasticity of the presentation." (70) A characterization of Steuermann's approach to op. 19 as form rendered plastic in sound is undoubtedly fitting.

[5.5] The many details singled out by Steuermann in his letter to Gielen and in his recordings reveal him to be very much the analytical performer that he has often been described as being - for example, in Adorno's obituary, which praises "the understanding of the music to be performed, articulated to the point of analysis" and the "making lucid of the particular structure of the concrete piece," precisely in opposition to Heinrich Schenker's tendency towards the universal, 
towards the "long arc" that, in the unfolding of the fundamental line (Urlinie), stretches across an entire piece. From this point of view - and this dynamic is palpable in the cited letter-Steuermann clearly focuses more on the detail than on the whole. Alongside the spontaneity and "drasticity" in expression attributed to him by Adorno, this analytical attention to the particular seems eventually to have given rise to an uncertainty with regard to success of pianistic shaping, addressed straightforwardly by Adorno as "considerable inhibition": "His ideal of interpretation had as its horizon the dawning uninterpretability of the works, just as Kafka's parables are inspired by the obscurity of sacred texts" (Adorno [1964] 1982, 313-15). ${ }^{(71)}$

[5.6] Example 27 shows some of the fundamental factors in the global course of the cycle. On the one hand, some striking particularities in Steuermann's curve are visible (most eye-catching are the peaks in $\mathrm{m} .7$ of no. 1, the consistently brisk tempo in no. 3, the idiosyncratic slowdown in no. 5, and the peaks in mm. 7 and 8 of no. 6). But on the other hand, in contrast to the abrupt and often extreme tempi in Kraus 1960 and Gould 1965, Steuermann always aims at a balance. It thus becomes clear that in Steuermann's performance, the parameter of tempo is used pointedly as a means of clarification and macro-formal structuring, a factor that appears much less pronounced in Henck 1994 or Pollini 1974, and that overall, as shown by the dashed curve of the mean values, has lost importance during the history of performance.

[5.7] In addition to the performance styles characteristic of the individual pianists, the results obtained by considering this corpus of recordings suggest a particularly broad potential for macroformal interpretational models in Schoenberg's op. 19. Without a doubt, the five models identified in section 3 of this article can also be applied to other contexts, as they are based on archaic prototypes of cyclical shaping: framing, opening, closing, contrasting, and accelerating. As we have shown, a unique feature in Steuermann's interpretations can be found in the tendency to navigate through these prototypes without taking one of them as an exclusive model for staging cyclic form, thus leaving space for the listener to grasp the multiplicity of meanings inherent in Schoenberg's formal design.

[5.8] Steuermann's differentiated approach to Schoenberg's piano works (and works by other composers) can still function today as a model for successful performances, precisely because it distances itself so thoroughly from a misunderstood conception of rationalized faithfulness to the text. ${ }^{(72)}$ That it also reveals the radical, unsettling facets of Schoenberg's short pieces makes this approach all the more valuable: it saves Steuermann's interpretations from furnishing Schoenberg's music with a classical or classicist character - a danger certainly inherent both in Steuermann's intention "to make it sound like normal music" (1942) and in the conspicuous canonization of Schoenberg's work in musical history and musical life. (This intention of presenting Schoenberg's revolutionary compositions as "normal music" may easily be explained by the Second Viennese School's struggle for institutional and music-historical recognition, but it certainly implies a tendency towards a normalization of musical interpretation, which arguably does not do justice to this school's outstanding works.)

[5.9] Striking departures from the expected course, even in recordings such as Herbert Henck's that stay very true to the text, show that principles of incommensurability, as inherent to Steuermann's readings, were taken up in some respects in later performances. And those interpretations that today in some aspects appear unsettling, such as those presented by Sanromá, Harris, Kraus, Gould, Majlingová, Liubimov, or Uchida, should thus in no way be understood as deficient or inferior to Steuermann's supposedly "authentic" interpretation, but rather as autonomous and worthwhile approaches that contribute to the historical unfurling of the inherent, unexplored potential of Schoenberg's musical ideas.

Christian Utz

University of Music and Performing Arts Graz

Leonhardstr. 15

A-8010 Graz

Austria

christian.utz@kug.ac.at 
Thomas Glaser

University of Music and Performing Arts Graz

Leonhardstr. 15

A-8010 Graz

Austria

thomas.glaser@kug.ac.at

\section{Works Cited}

Theodor W. Adorno. (1958) 1976. Der getreue Korrepetitor. Lehrschriften zur musikalischen Praxis. In Gesammelte Schriften, vol. 15, ed. Rolf Tiedemann, 157-402. Suhrkamp.

. (1964) 1982. “Nach Steuermann's Tod." In Musikalische Schriften IV (Gesammelte Schriften, vol. 17), ed. Rolf Tiedemann, 311-18. Suhrkamp.

- 2001. Zu einer Theorie der musikalischen Reproduktion. Aufzeichnungen, ein Entwurf und zwei Schemata, ed. Henri Lonitz. Suhrkamp.

- 2006. Towards a Theory of Musical Reproduction. Edited by Henri Lonitz. Translated by Wieland Hoban. Polity Press.

Barthes, Roland. 1986a. "The Romantic Song." In The Responsibility of Forms: Critical Essays on Music, Art, and Representation, trans. Richard Howard, 286-92. Blackwell.

1986b. “Loving Schumann.” In The Responsibility of Forms: Critical Essays on Music, Art, and Representation, trans. Richard Howard, 293-98. Blackwell.

1986c. "Rasch." In The Responsibility of Forms: Critical Essays on Music, Art, and

Representatio, trans. Richard Howard, 299-312. Blackwell.

Caplin, William E. 1998. Classical Form: A Theory of Formal Functions for the Instrumental Music of Haydn, Mozart, and Beethoven. Oxford University Press.

Cook, Nicholas. 1995. “The Conductor and the Theorist: Furtwängler, Schenker and the First Movement of Beethoven's Ninth Symphony." In The Practice of Performance: Studies in Musical Interpretation, ed. John Rink, 104-25. Cambridge University Press. https://doi.org/10.1017/CBO9780511552366.006.

1999. “Analysing Performance and Performing Analysis." In Rethinking Music, ed. Nicholas Cook and Mark Everist, 239-61. Oxford University Press.

2013. Beyond the Score: Music as Performance. Oxford University Press. https://doi.org/10.1093/acprof:oso/9780199357406.001.0001.

. 2017. “Inventing Tradition: Webern's Piano Variations in Early Recordings.” Music Analysis 36 (2): 163-215, https://doi.org/10.1111/musa.12094.

Cramer, Alfred. 2002. “Schoenberg's Klangfarbenmelodie: A Principle of Early Atonal Harmony." Music Theory Spectrum 24 (1): 1-34.

Danuser, Hermann. 1997. “Musikalische Interpretation." In Im Zenit der Moderne. Die Internationalen Ferienkurse für Neue Musik Darmstadt 1946-1966, vol. 2: Geschichte [2], ed. Gianmario Borio and Hermann Danuser, 119-87. Rombach.

Deliège, Irène. 2001. “Prototype Effects in Music Listening: An Empirical Approach to the Notion of Imprint." Music Perception 18 (3): 371-407. https://doi.org/10.1525/mp.2001.18.3.371.

DeLio, Thomas. 1994. "Language and Form in An Early Atonal Composition: Schoenberg's Opus 19, No. 2." Indiana Theory Review 15 (2): 17-40. 
Doğantan-Dack, Mine. 2008. “Recording the Performer's Voice." In Recorded Music: Philosophical and Critical Reflections, ed. Mine Doğantan-Dack, 293-313. Middlesex University Press.

Dünki, Jean-Jacques. 2006. Schönbergs Zeichen. Wege zur Interpretation seiner Klaviermusik. Lafite.

Epstein, David. 1995. Shaping Time: Music, the Brain, and Performance. Schirmer.

Fearn, Raymond. 2002. "Sechs kleine Klavierstücke op. 19." In Arnold Schönberg. Interpretationen seiner Werke, vol. 1, ed. Gerold Gruber, 269-81. Laaber.

Feß, Eike. 2018. "Aufführungspraxis der Wiener Schule im Verein für musikalische Privataufführungen." Journal of the Arnold Schönberg Center 15: 31-51.

Gould, Glenn. 1984. “The Piano Music of Arnold Schoenberg.” In The Glenn Gould Reader, ed. Tim Page, 122-28. Knopf.

Grassl, Markus, and Reinhard Kapp, eds. 2002. Die Lehre von der musikalischen Aufführung in der Wiener Schule. Verhandlungen des Internationalen Colloquiums Wien 1995. Böhlau.

Haack, Helmut. 2002. "Was ist musikalische Zeit? Tempolehre und Tempopraxis (in der zweiten Wiener Schule) im Lichte vergleichender Forschungen an historischen Tondokumenten." In Die Lehre von der musikalischen Aufführung in der Wiener Schule, ed. Reinhard Kapp and Markus Grassl, 223-55. Böhlau.

Hill, Robert, and Claus-Steffen Mahnkopf. 2015. “Quo vadis, 'Alte Musik'? Zur Rolle der Zeitgestaltung in der historisierenden Aufführungspraxis der Zukunft. Ein Gespräch mit Robert Hill." Musik E Ästhetik 19 (73): 5-23.

Jacob, Andreas. 2005. Grundbegriffe der Musiktheorie Arnold Schönbergs. 2 vols. Olms.

Janssen, Jürgen, and Wilfried Laatz. 1994. Statistische Datenanalyse mit SPSS für Windows. Springer. https://doi.org/10.1007/978-3-662-13046-9.

Kapp, Reinhard. 1996. “Die Stellung Schönbergs in der Geschichte der Aufführungslehre.” In Bericht über den 3. Kongreß der Internationalen Schönberg Gesellschaft. "Arnold Schönberg - Neuerer der Musik." Duisburg, 24. bis 27. Februar 1993, ed. Rudolf Stephan and Sigrid Wiesmann, 85-101. Lafite.

Kolisch, Rudolf. 1983. Zur Theorie der Aufführung. Ein Gespräch mit Berthold Türcke (Musik-Konzepte 29/30). edition text+kritik.

Kopfermann, Michael. 1980. “Über Schönbergs Klavierstück Op. 19, Nr. 2. Analytischer Versuch zur Harmonie." In Arnold Schönberg (Musik-Konzepte Sonderband), ed. Heinz-Klaus Metzger and Rainer Riehn, 35-50. edition text+kritik.

Kraus, Else C. 1974. “Schönbergs Klavierwerk steht lebendig vor mir.” Melos 41 (3): 134-40.

Laubhold, Lars E. 2014. Von Nikisch bis Norrington. Beethovens 5. Sinfonie auf Tonträger. Ein Beitrag zur Geschichte der musikalischen Interpretation im Zeitalter ihrer technischen Reproduzierbarkeit. edition text+kritik.

. 2018: "Eduard Steuermann als Schönberg-Interpret. Zu den Tondokumenten der Sechs kleinen Klavierstücke op. 19." Journal of the Arnold Schönberg Center 15: 66-82.

Leech-Wilkinson, Daniel. 2009. The Changing Sound of Music: Approaches to Studying Recorded Musical Performances. CHARM. http://www.charm.rhul.ac.uk/studies/chapters/intro.html.

2012. “Compositions, Scores, Performances, Meanings." Music Theory Online 18 (1).

https://doi.org/10.30535/mto.18.1.4.

Leichtentritt, Hugo. 1928. “Schönberg and Tonality." Modern Music 5 (4): 3-10.

Lendvai, Ernő. 1971. Béla Bartók: An Analysis of his Music. Kahn. 
Leong, Daphne, and Hunter Ewen. 2019. “Creation of Structure: Interpreting Schoenberg's Klavierstück, Op. 19, No. 4." In Daphne Leong, Performing Knowledge: Twentieth-Century Music in Analysis and Performance, 59-96. Oxford University Press.

Leonhart, Rainer. 2020. “Fishers Z-Transformation.” In Dorsch-Lexikon der Psychologie, ed. Markus Antonius Wirtz. Hogrefe. https://portal.hogrefe.com/dorsch/fishers-z-transformation.

Lester, Joel. 1995. "Performance and Analysis: Interaction and Interpretation." In The Practice of Performance: Studies in Musical Interpretation, ed. John Rink, 197-216. Cambridge University Press. https://doi.org/10.1017/CBO9780511552366.010.

Levinson, Jerrold. 1997. Music in the Moment. Cornell University Press.

Lewin, David. 1982. “Transformational Techniques in Atonal and Other Music Theories.” In Perspectives of New Music 21 (1/2): 312-71. https://doi.org/10.2307/832879.

Massow, Albrecht von. 1993. "Abschied und Neuorientierung - Schönbergs Klavierstück op. 19,6." Archiv für Musikwissenschaft 50 (2): 187-95.

McKee, Eric. 2005. “On the Death of Mahler: Schoenberg's Op. 19, No. 6.” Theory and Practice 30: 12151.

Morris, Robert D. 1993. "New Directions in the Theory and Analysis of Musical Contour." Music Theory Spectrum 15 (2): 205-28.

Moßburger, Hubert. 2014. "Hermeneutische Analyse. Arnold Schönberg: Klavierstück op. 19 Nr. 2." In Musikalische Analyse: Begriffe, Geschichten, Methoden, ed. Felix Diergarten, 185-217. Laaber.

Obert, Simon. 2008. Musikalische Kürze zu Beginn des 20. Jahrhunderts. Steiner.

Philip, Robert. 1992. Early Recordings and Musical Style: Changing Tastes in Instrumental Performance, 1900-1930. Cambridge University Press. https://doi.org/10.1017/CBO9780511470271.

Quick, Miriam Siân. 2011. “Performing Modernism: Webern on Record.” PhD diss. King's College. University of London.

Ratz, Erwin. 1973. Einführung in die musikalische Formenlehre. Über Formprinzipien in den Inventionen und Fugen J. S. Bachs und ihre Bedeutung für die Kompositionstechnik Beethovens. 3rd ed. Universal Edition.

Repp, Bruno. 1992. “Diversity and Commonality in Music Performance: An Analysis of Timing Microstructure in Schumann's 'Träumerei."' The Journal of the Acoustical Society of America 92 (5): 227-60. https://doi.org/10.1121/1.404425.

Rink, John. 2002. "Analysis and/or Performance?" In Musical Performance: A Guide to Understanding, ed. John Rink, 35-58. Cambridge University Press. https://doi.org/10.1017/CBO9780511811739.004.

\section{Press.}

Sallmen, Mark. 2016. “Transposition Networks and Network Chains in Schoenberg's Sechs kleine Klavierstücke, Op. 19." Intégral 30: 13-30.

Schmidt, Dagmar. 1993. Arnold Schönberg: seine Klavierstücke op. 19 und das Phänomen des Expressionismus. Molsen.

Schoenberg, Arnold. 1909. Letter to Busoni, Steinakirchen am Forst, 24 August, 1909. https://busoninachlass.org/en/Correspondence/E010001/D0100014.html. 
Press.

. (1912) 1975a. “Gustav Mahler: In Memoriam". In Style and Idea, ed. Leonard Stein, trans. Leo Black, 447-48. Faber and Faber.

. (1912/48) 1975b. “Gustav Mahler". In Style and Idea, ed. Leonard Stein, trans. Dika Newlin, 449-71. Faber and Faber.

. ca. 1923-24. "Zur Vortragslehre." typescript T36.05. Arnold Schönberg Center. http://archive.schoenberg.at/writings/edit_view/transcription_view.php? id=332\&word_list=Zur\%20Vortragslehre.

1934/36. “Der musikalische Gedanke und die Logik, Technik und Kunst seiner

Darstellung", typescript. Arnold Schönberg Center, T65.03.

http://archive.schoenberg.at/writings/edit_view/transcription_view.php?

id=203\&word_list=Der\%20musikalische\%20Gedanke\%20und\%20die\%20Logik,\%20Technik\%20und\%20Kunst\%20st

1967. Fundamentals of Musical Composition. Edited by Gerald Strang and Leonard Stein.

Faber and Faber.

Sprau, Killian. 2017. “Das Lied als Fragment. Zur Frage der Zyklizität in Liedkompositionen des 19. Jahrhunderts." In Musiktheorie im 19. Jahrhundert. 11. Jahreskongress der Gesellschaft für Musiktheorie in Bern 2011, ed. Martin Skamletz, Michael Lechner, and Stephan Zirwes, 302-11. Edition Argus.

Stenzl, Jürg. 1995. "In Search of a History of Musical Interpretation." The Musical Quarterly 79 (4): 683-99. https://doi.org/10.1093/mq/79.4.683.

2018. "Interpretationsgeschichte der 'Wiener Schule'? Eine Spurensuche." Journal of the Arnold Schönberg Center 15: 11-30.

Steuermann, Eduard. 1928. “Urtext und praktische Ausgabe.” Pult und Taktstock 5 (8-9): 85-87. 1942. Letter to Michael Gielen, July 24, 1942. Edward and Clara Steuermann Collection. Library of Congress, Music Division.

1989. The Not Quite Innocent Bystander: Writings of Edward Steuermann. Edited by Clara Steuermann, David Porter, and Gunther Schuller. University of Nebraska Press.

Stuckenschmidt, Hans Heinz. 1974. Schönberg. Leben - Umwelt-Werk. Atlantis. 1977. Schoenberg: His Life, World, and Work. Translated by Humphrey Searle. Calder.

Swinkin, Jeffrey. 2016. Performative Analysis: Reimagining Music Theory for Performance. University of Rochester Press.

Taruskin, Richard. 2010. Music in the Early Twentieth Century. Vol. 4 of The Oxford History of Western Music. Revised Edition. Oxford University Press.

Tillmann, Barbara, and Emmanuel Bigand. 2004. "The Relative Importance of Local and Global Structures in Music Perception." The Journal of Aesthetics and Art Criticism 62 (2): 211-22. https://doi.org/10.1111/j.1540-594X.2004.00153.x.

Ünlü, Altuğ. 2016. “Das Modell der Achsensymmetrie in Schönbergs op. 19, Nr. 4.” Musik E Ästhetik 20 (78): 32-43.

Utz, Christian. 2015. Review of Beyond the Score: Music as Performance, by Nicholas Cook. Zeitschrift der Gesellschaft für Musiktheorie 12 (2): 275-83. https://doi.org/10.31751/826.

2016. "Räumliche Vorstellungen als “Grundfunktionen des Hörens." Historische Dimensionen und formanalytische Potenziale musikbezogener Architektur- und Raummetaphern 
- Eine Diskussion anhand von Werken Guillaume Dufays, Joseph Haydns und Edgard Varèses." Acta Musicologica 88 (2): 193-222.

2017a. “Time-Space Experience in Works for Solo Cello by Lachenmann, Xenakis, and Ferneyhough: A Performance-Sensitive Approach to Morphosyntactic Musical Analysis." Music Analysis 36 (2): 216-56. https://doi.org/10.1111/musa.12076.

2017b. “Komponierte, interpretierte und wahrgenommene Zeit. Zur Integration temporaler Strukturen in eine performative Analyse - eine Diskussion anhand von Johann Sebastian Bachs Goldberg-Variationen." Musik \& Ästhetik 21(82): 5-23.

2018. "Multivalent Form in Gustav Mahler's Lied von der Erde from the Perspective of Its Performance History." Musicologica Austriaca. http://musau.org/parts/neue-article-page/view/37.

2019a. "Form und Sinn in Gustav Mahlers Abschied. Konkurrierende Deutungen in der Geschichte der Mahler-Interpretation." In Musik im Zusammenhang. Festschrift Peter Revers zum 65. Geburtstag, ed. Klaus Aringer, Christian Utz and Thomas Wozonig. 685-722. Hollitzer. https://phaidra.kug.ac.at/o:104445.

2019b. Review of Performative Analysis: Reimagining Music Theory for Performance by Jeffrey Swinkin. Music Theory Spectrum 41 (1): 179-83. https://doi.org/10.1093/mts/mtz001.

forthcoming. "Zur Plastizität verklanglichte Form: Tempo-, Klang- und Formgestaltung in Eduard Steuermanns Einspielungen von Arnold Schönbergs Sechs kleinen Klavierstücken op. 19 im Kontext der Interpretationsgeschichte des Werkes." In Eduard Steuermann: Musiker und Virtuose, ed. Lars E. Laubhold. edition text+kritik.

Utz, Christian and Thomas Glaser. 2020. "Gestaltete Form. Interaktion von Mikro- und Makroform in 46 Interpretationen (1925-2018) von Arnold Schönbergs Sechs kleinen Klavierstücken op. 19.” In Aufführung und Interpretation. Aspekte, Perspektiven, Diskussionen zur performativen Expressivität des KClaviers, ed. Claus Bockmaier and Dorothea Hofmann, 155-220. Allitera.

Väisälä, Olli. 1999. “Concepts of Harmony and Prolongation in Schoenberg's Op. 19/2." Music Theory Spectrum 21 (2): 230-59. https://doi.org/10.2307/745863.

Widmer, Gerhard. 2002. "In Search of the Horowitz Factor: Interim Report on a Musical Discovery Project." In Discovery Science. 5th International Conference, DS 2002 Lübeck, Germany, November 24-26, 2002 Proceedings, ed. Steffen Lange, Ken Satoh, and Carl H. Smith, 13-32. Springer.

Widmer, Gerhard, Simon Dixon, Werner Goebl, Elias Pampalk, and Asmik Tobudic. 2003. “In Search of the Horowitz Factor.” AI Magazine 24 (3): 111-30. https://doi.org/10.1007/3-540-36182-0_4.

\section{Scores}

Schönberg, Arnold. 1968. Sämtliche Werke. Abteilung II. Klavier- und Orgelmusik. Reihe A, Band 4. Edited by Eduard Steuermann and Reinhold Brinkmann. Schott.

_. 2012. Sechs kleine Klavierstücke op. 19. Faksimile. Edited by Christian Meyer. Universal Edition.

\section{Footnotes}

* This article summarizes two publications in German by the authors (Utz and Glaser 2020, Utz forthcoming). A preliminary German version of the present essay was translated by Maxwell Phillips, to whom we express our sincere thanks, and further edited by the authors and the translator for publication. The research documented in this article was conducted as part of the research project Performing, Experiencing and Theorizing Augmented Listening (PETAL), supported by the Austrian Science Fund FWF (P 30058-G26, 1/9/2017-31/8/2020). Laurence Willis (a contributor to the project until December 31, 2018) played a crucial part in the genesis and formation of the 
annotated score described below, for which we thank him warmly. Majid Motavasseli (a contributor to the project since January 1, 2019) provided valuable assistance in the detailed listening analysis of Steuermann's three studio recordings of op. 19. We would also like to thank Bruno Gingras (University of Innsbruck) and Oscar Bandtlow (Queen Mary University of London) for support in the interpretation and description of the statistical data.

Return to text

1. Cook describes performance and analysis here as "interlocking modes of musical knowledge" (1999, 248).

Return to text

2. See, for instance, Cook 2013, Leech-Wilkinson 2009, Doğantan-Dack 2008, and Rink 2002. Much of this research was recently updated and collected in a comprehensive five-volume anthology (Rink 2017-18).

Return to text

3. Regarding the relevance of this topic in the context of the Second Viennese School's performance aesthetics See [2.8].

Return to text

4. Earlier studies that follow this methodology include Utz 2017a, 2017b, 2018, and 2019a.

Return to text

5. For contributions to this discussion in philosophy, music psychology, and music theory, see, among others, Levinson 1997, Tillmann and Bigand 2004, and Utz 2016.

Return to text

6. The discography of the Arnold Schönberg Center

(https://www.schoenberg.at/diskographie/works/019a.htm), which includes most of the recordings published before 2003, served as the basis for our discographic research. We have found a total of 82 recordings of the Klavierstücke op. 19 by 72 pianists between 1925 and 2018. Multiple recordings exist, in addition to Steuermann, from Johana Harris (1951, 1954), Else C. Kraus (1952, 1960), Paul Jacobs $(1958,1968,1975)$, and Jean Rodolphe Kars $(1969,1974)$.

Return to text

7. The authors address implicit and procedural knowledge of expert performers in performances of Schoenberg's op. 19, based on a grounded-theory approach developed from extensive workshop audio material in Utz and Glaser 2020, 202-10.

Return to text

8. The annotated score can be accessed and downloaded at https://phaidra.kug.ac.at/o:98015. The tempo data in this score represent an earlier stage of our research (from February 2018), which differs from the data presented in this article. Updated data sets that constitute the data used for creating the tables and diagrams of the present article can be accessed at the GitHub repository https://github.com/petal2020/petal_schoenberg_op_19.

Return to text

9. Unless otherwise stated, all translations are by the authors.

Return to text

10. See Theodor W. Adorno's analysis of Webern's Sechs Bagatellen für Streichquartett, op. 9 (1913): “Indem sie [die neue Musik] nämlich die traditionellen Formen vermeidet, bewahrt sie diese auf. Noch die freiesten und unschematischsten Gebilde enthalten die Spur geschichtlicher Tektonik.

Analyse kann das aufdecken, und Interpretation muß daran anschließen" (By avoiding the traditional forms, [new music] preserves them. Even the freest and most unschematic formations contain the traces of historical tectonics. Analysis can reveal this, and interpretation must follow.) ([1958] 1976, 279-80). A detailed analysis may attempt to reveal to what extent any given performance of a piece such as op. 19 , no. 1, renders such hidden traditionalisms audible or, on the 
contrary, plays against them.

Return to text

11. At the same time, the tempo for this piece is left relatively open: with "Leicht, zart," Schoenberg refrains from clearly defining the tempo, in contrast to the five following pieces.

Return to text

12. On these references, see [4.37]-[4.38].

Return to text

13. Certainly one could consider the held G3 at the end of the third piece as a "neighbor note" separated by two octaves from the F5, the first note of the fourth piece (and in the first autograph, Schoenberg indeed suggests such a relationship with a tie from this G3 across the final barline of the piece). Nonetheless, the contrast in tempo and character between these two pieces creates a clear break, which is reinforced by the change in register.

Return to text

14. See particularly Leichtentritt 1928, Schmidt 1993, Fearn 2002, and Sallmen 2016. With respect to individual pieces, particular attention is paid in the analytic literature to no. 2 (Kopfermann 1980; DeLio 1994; Väisälä 1999; Moßburger 2014, no. 4 (Morris 1993; Ünlü 2016), and no. 6 (Lewin 1982; McKee 2005).

Return to text

15. This refers to Schoenberg's aesthetics around 1909-11 which he explicated, among others, in a famous letter to Busoni. In this letter, Schoenberg advocated musical creation from the unconscious: Letter from Schoenberg to Busoni, Steinakirchen am Forst, August 24, 1909, https://busoni-nachlass.org/en/Correspondence/E010001/D0100014.html.

Return to text

16. See Cook 2013, 9-16 and 31. In his study of the performance history of Anton Webern's Variations for Piano, op. 27, however, Cook (2017) demonstrates how the central premises of the performance practice of the Second Viennese School came into conflict with an explicitly textcentered performance style of new music after 1945. See also Quick 2011, 61-105.

Return to text

17. “Wahre Reproduktion ist nicht einfach die Realisierung des analytischen Befundes (der übrigens prinzipiell nicht als abgeschlossener vorzustellen ist). Sondern sie enthält das idiomatische Element als aufgehobenes in sich. Und damit schließt sie notwendig die Subjektivität des Interpreten ein, die jedem Werk gegenüber das idiomatische Element repräsentiert [. . .]. Sie ist also weder die irrationale (idiomatische) noch die chemisch-reine, analytische, sondern die Wiederherstellung des mimischen Elements durchs analytische hindurch" (Adorno 2001, 91; italics in the original).

Return to text

18. See Kapp 1996, 99-101. See also, among others, Schoenberg ca. 1923-24, Steuermann 1928, Kolisch 1983, Grassl and Kapp 2002, Haack 2002, Stenzl 2018, and Feß 2018.

Return to text

19. “Nach jedem Stück ausgiebige Pause, die Stücke dürfen nicht ineinander übergehen!” Return to text

20. This instruction was included in the first edition of the score, which was published by Universal-Edition (U.E. 5069) in October 1913 (see http://archive.schoenberg.at/compositions/werke_einzelansicht.php? werke_id=191\&herkunft=allewerke), and was thus added after the first performances of the cycle on January 22 and February 4, 1912.

Return to text 
21. “Im Ganzen nahm er alles zu rasch; oder vielmehr zu eilig. Ich sagte zu Webern: zu meiner Musik muß man Zeit haben. Die ist nichts für Leute, die anderes zu tun haben. Aber es ist jedenfalls ein großes Vergnügen, seine Sachen von jemandem zu hören, der sie technisch vollkommen beherrscht" (Stuckenschmidt 1974, 145).

Return to text

22. For a striking example of this approach, see Alfred Cortot's 1923 recording of Schumann's Carnaval. Available on CD: Cortot Plays Schumann - Volume II, Pearl - GEMM CD 9932 (1992). Return to text

23. A (normalized) transcription of this letter can be found in Steuermann 1989, 104-5. Excerpts from the letter are cited here from the autograph (Edward and Clara Steuermann Collection, Library of Congress, Music Division, quoted as Steuermann 1942). We sincerely thank Martin Zenck for making this document available to us. A complete transcription of the autograph letter can be found in Utz forthcoming.

Return to text

24. In this essay, all tempi are given as beats per minute (bpm). Tempo was measured in Sonic Visualiser and follows the pulse given by Schoenberg for each piece in the score with the exception of no. 2, where the tempo was measured according to the eighth-note pulse of the ostinato (tempi for no. 2, however, will be given here in quarter notes per minute, in accordance with the pulse indicated in the score). Measures in which Schoenberg indicates a tempo change-for example, ritardandi and fermatas - were excluded from the calculation of the main tempo of a recording. Return to text

25. We do not elaborate theories of dramaturgy in this context and refer to "dramaturgies" as the most intuitive term for what the macroformal models explored describe (framing, opening, finale, contrast, accelerando).

Return to text

26. The terms "distant listening" and "close listening" were coined by Nicholas Cook (2013, chaps. 5 and 6) in an analogy to the methods of "close reading" and "distant reading" in literary studies. Cook's fundamental claim is to combine corpus studies of musical recordings ("distant listening") -thus avoiding tautological results, in which researchers merely retrieve what they have "heard into" the recordings - with traditional methods of "close listening," so that micro- and macroscopic perspectives on recordings (and thus on the interpreted works) can continually comment on and correct each other.

Return to text

27. Dynamics (loudness) will be discussed repeatedly in the close listening descriptions of recordings provided in the subsequent sections. There is, however, no attempt to consider dynamics comprehensively for all recordings similarly to what we have attempted for durations and tempo. The reason for this is, first, that measured dynamics would have to be allocated to established categories such a $f, m f$, or $p$ for each recording anew and individually, and, second, that structurally complex music such as Schoenberg's op. 19 usually requires more than one dynamic degree for each measured instant. In Utz and Glaser 2020, 192-98, we have, however, used dynamic measurements for three recordings of op. 19, no. 3, to demonstrate correlations and divergences between performed tempo and dynamics in a single case study.

Return to text

28. An "urge to expression" [Ausdrucksbedürfnis] forms the center of Schoenberg's thoughts on composition: "In composing I make decisions only according to feeling, according to the feeling for form. This tells me what I must write; everything else is excluded. Every chord I put down corresponds to a necessity, to a necessity of my urge to expression; perhaps, however, also to the necessity of an inexorable but unconscious logic in the harmonic structure" (Schoenberg [1911/22] 1978, 417). "Ich entscheide beim Komponieren nur durch das Gefühl, durch das Formgefühl. Dieses sagt mir, was ich schreiben muß, alles andere ist ausgeschlossen. Jeder Akkord, den ich hinsetze, entspricht einem Zwang; einem Zwang meines Ausdrucksbedürfnisses, vielleicht aber 
auch dem Zwang einer unerbittlichen, aber unbewußten Logik in der harmonischen Konstruktion" (Schoenberg [1911] 1922, 499).

Return to text

29. Here, as well as frequently in the remaining article, values are given with the mean value added after a slash.

Return to text

30. This value indicates the difference between the percent values for the first and sixth piece in each recording; in Majlingová 1977, the percent value for the first piece is 12.3 percentage points higher than for the sixth.

Return to text

31. In many recordings, as noted in Steuermann's letter to Gielen (Steuermann 1942), a consistent main tempo can hardly be distinguished. This is especially the case for several recordings before 1970 and moreover particularly for nos. 1 and 6, where the score contains a large number of tempo modifications (no. 1), or where the static texture frustrates the perception of a tempo in the narrower sense (no. 6).

Return to text

32. In the case of Johana Harris, it is difficult to avoid the impression of certain pianistic shortcomings, as suggested by Lars Laubhold; her interpretation, according to Laubhold, lacks "structural clarity entirely. Under her fingers, the piece [no. 1] becomes an ethereal-esoteric soundmystery, which requires neither high points nor internal structure, and no agogic interpretation to speak of" (strukturelle Klarheit [. . .] gänzlich. Unter ihren Fingern wird das Stück zu einem ätherisch-esoterischen Klang-Mysterium, das weder Höhepunkte noch Binnenstruktur und schon gar keine agogische Ausdeutung braucht) $(2018,80)$. In any case, this recording from the Cumberland Forest Festival, which may well have been made under difficult conditions, should be compared in a further study with her later recording (Harris 1954), which unfortunately was not available to us.

Return to text

33. Dünki $(2006,122)$ is here far beneath his suggested tempo of $\delta=100$.

Return to text

34. Dünki (2006, 123), for instance, recommends a "deep breath" [tiefen Atemzug] in m. 4.4.

Steuermann, in contrast, writes in the letter to Gielen: "The deviations from the general tempo (for instance in the first piece) should be as slight as possible, (I don't know how far advanced you are in controlling the tempo, when you don't play with metronom[e]). [T] he technique of the Halbund Viertelschluesse must be mastered very well, otherwise the piece would be disrupted" (1942). Return to text

35. Attention must be drawn to the, at first, seemingly contradictory finding that Kraus's chosen main tempo (82.7 bpm) lies actually $4.8 \mathrm{bpm}$ under the average $(87.6 \mathrm{bpm})$, but the movement's duration (1:06) is ten seconds shorter than the average (1:16). This surprising result is due to the fact that Kraus accelerates dramatically in the passages excluded in the calculation of the main tempo (mm. 2.2-2.6, 11.2-12, and 14-17, see footnotes 24 and 38), especially in mm. 14-17 (see Example 8), so that a shorter duration results than would be expected based on the choice of main tempo.

Return to text

36. The relative standard deviation, given as a percent of the main tempo, can generally be taken as a measure of the volatility of the tempo in a recording or the degree of rubato employed. The use of relative standard deviation would require a more detailed discussion than is possible in the given context. The values given here are based on deviations only in those passages considered for the measurement of the main tempo-i.e., in the measures where no tempo modifications are given in the score (see footnote 24). It can nonetheless also be instructive to consider the relative standard deviation from the main tempo for all tempo values from the first piece. The two relative standard 
deviation values (with and without consideration of the "variance measures") show significant differences. For instance, in Harris 1951, a recording that stands out in many ways, the value excluding the variance measures is relatively inconspicuous at 30.2/27.4, while including these measures gives at 47.0/34.2 the second highest value of all the recordings and thus better reflects the impression of an extreme fluctuation in the tempo.

Return to text

37. In Uchida's recording, the percent value for no. 6 is 13.9 percentage points higher than for no. 1. Return to text

38. Here too we point to the surprising result (see footnote 35) that, despite a main tempo considerably faster (by $17.4 \mathrm{bpm}$ ) than the average, the duration of Uchida's first piece is in fact five seconds longer than the mean duration. This is in part due to the other pianists' dramatic deceleration in the measures not considered in calculating the main tempo (mm. 2.2-2.6 and 11-12; see Example 9), but also because of stark fluctuations of the tempo in the passages that were considered (e.g., from m. 3.6: $133 \mathrm{bpm}$ to m. 4.4: $56 \mathrm{bpm}$, and many similar passages), so that the main tempo here must be considered as largely "fictive" (see footnote 31 ).

Return to text

39. This results in the shortest duration for no. 1 (0:55), also reached by Karl Steiner 1962. Steiner's slower main tempo (118.9) indicates that he decelerates less than Liubimov in the measures with tempo modifications.

Return to text

40. A faster tempo for no. 5 can only be found in Zykan 1970 (205.0/141.6; 0:17/0:29) and Sanromá 1937 (229.6/141.6; 0:18/0:29). In Zykan, this quick tempo is part of a fragmentation of nos. 2-6 in the context of the opening model (see [3.6]), and in Sanromá, an intensification in the context of the accelerando model (see [3.13]).

Return to text

41. See footnote 8 .

Return to text

42. An alternative interpretation, which puts the beginning of the development in $\mathrm{m}$. 7, can lay claim to many of the recordings, which slow down dramatically in the complex figure that reaches into the high register in $\mathrm{m} .6$, while the tremolo in $\mathrm{m} .8 .2$ emerges directly out of the figure marked "flüchtig" from the beginning of the bar, which itself emerges as the result of the rhythmic acceleration of $\mathrm{m}$. 7. In any case, the moment of thematic contrast, fundamental to Schoenberg's own understanding of sonata form (see, among others, Schoenberg's "Entwurf einer Vortragsreihe" (T50.19), undated, in Jacob 2005, 2:675), is more clearly pronounced in $\mathrm{m} .7$ than in mm. 4.5-6.3 (which alternatively might be understood as a "secondary theme"). This earlier phrase, in its chromatically falling line (see the melodic-harmonic analysis in the annotated score) and its polyphonic structure, has a more typically transitional character, while the thematic contrast of figure in $\mathrm{m} .7$ is marked compositionally by a change in the texture and motivic content (the double-dotted rhythm). In the end, these "formalistic" considerations are of limited relevance here, as a form created in the act of performance occupies the center of our discussion.

Return to text

43. As mentioned in footnote 31, a consistent main tempo can hardly be discerned in many interpretations, especially for no. 1, so that the values here frequently take on the character of a first approximation. This is generally the case for many interpretations before 1970 and particularly relevant for nos. 1 and 6 .

Return to text

44. This point is discussed in detail in Utz forthcoming. See also Laubhold 2018, 76-77.

Return to text

45. See Cook 2013, 212-22, where the praxis and theory of phrase arching, fundamental for a "structuralist performance style," is broadly cultural-historically contextualized. 
46. In the first autograph, Schoenberg had also indicated a "rit. . .." from m. 1.6 to 2.1. This marking was removed in the printed edition, likely with the intention of not dividing up the phrasing too much.

Return to text

47. "The skill in taking up the tempo immediately must be very good (can be controlled by metronom[e]) [...]. The more you are able to give the impression of the constant tempo, the better. (The melody in bar 13 should be somehow the same voice which started in the beginning)" (Steuermann 1942; emphasis in the original). This can be interpreted above all in relation to the tempo-correspondence between the first and third sections of no. 1.

Return to text

48. It is important to keep in mind that these values are meaningful only in relation to the Steuermann recording. Similar coefficients for two (other) recordings, especially in the case of similarly low values, in no way indicate that these recordings will correlate strongly with each other (for example, although in no. 1 Henck 1994 and Harris 1951 both have a correlation coefficient with Steuermann 1963 of 0.428 , these two recordings could hardly be more different, since their correlation to one another is merely 0.249 ). To put it another way, individual recordings might correlate more or less strongly with Steuermann's interpretation for different reasons (in the case of Henck, a very stable conception of the tempo throughout, and for Harris, in contrast, an extremely instable conception).

Return to text

49. See Janssen and Laatz 1994, 531-58. Factor analysis was first used as a method for comparing tempo curves by Repp 1992.

Return to text

50. See, among others, Kopfermann 1980, DeLio 1994, and Moßburger 2014.

Return to text

51. "> oder sf bedeutet stets nur eine kleine, der Umgebung angemessene Betonung. Diese Betonung darf stärker sein, als die dem betreffendem [sic] Taktteil zukommende, muss sich aber wohl unterscheiden von den durch: $\mathrm{mfp}$, fp, mfpp, fpp oder gar ffpp bezeichneten Stellen, bei welchen wirklich einzelne Töne durch ihre Stärke aus der Umgebung herausfallen, um, eventuell durch sofortige Abdämpfung, gleich nachher wieder dem Vorhergehenden sich anzupassen" (Arnold Schönberg, Sechs kleine Klavierstücke op. 19, autograph fair copy, http://archive.schoenberg.at/compositions/quellen_einzelansicht.php? id_quelle=1594\&werke_id=191\&id_gatt=\&id_untergatt=\&h erkunft=allewerke, italics added). See also Schönberg 2012.

Return to text

52. The first printed edition reinserts the accent to the right hand's chord in $\mathrm{m}$. 5.1, while omitting the left hand's accents in mm. 4.2 and 5.1, reducing these two emphases to a tenuto dash.

Return to text

53. “Die Wurzel der Vieldeutigkeit liegt wohl in der Notenschrift selbst, die, weit davon entfernt, Musik vollkommen wiederzugeben, den Komponisten zwingt, seine 'wirkliche' musikalische Vision durch übernommene Kulturübereinkommen auszudrücken. Und so ist das 'Zwischen den Zeilen lesen' eben, was das Musikstück erst zu einem Kunstwerk macht, mag dabei noch so stark betont werden, daß 'zwischen den Zeilen lesen' die Zeilen richtig lesen heißt." (The root of ambiguity lies indeed in the musical notation itself, which, far from representing music completely, forces the composer to express his 'real' musical vision through received cultural conventions. And thus it is 'reading between the lines' that first makes a piece of music a work of art, although it should be emphasized just as strongly that 'reading between the lines' means reading the lines correctly.) (Steuermann 1928, 85-86.)

Return to text 
54. The terminology used here is based on the theory of formal functions in Caplin 1998, which can be traced back to Schoenberg's (1967) and Erwin Ratz's (1973) writings on musical form. The categorization here of mm. 1-4 as a "compound basic idea" slightly contradicts the separation of a "basic idea" (mm. 1-2) and "basic idea varied" (mm. 3-4) in our annotated score. Fundamentally, both categorizations are possible, with the "compound basic idea" perhaps better expressing the idea of a polyphonic intertwining of multiple layers of motives and phrases, while the separation into two parts puts the focus on the phrase structure of the upper staff. (In addition, it might be argued that mm. 3-4 represent a Fortspinnung, not a variation of the first two bars.) See further Utz and Glaser 2020, 192 and 213.

Return to text

55. Liubimov's interpretation, in the other pieces remarkable for its many idiosyncrasies, in this case follows a largely conventional path. There is, however, a mistake in $\mathrm{m}$. 6: he plays the last note of the measure as $\mathrm{D} b 4$ instead of $\mathrm{D}^{\sharp} 4$. Whether this is perhaps traceable to a mistake in a (Russian?) edition cannot be decided here.

Return to text

56. The "poco rit." in $\mathrm{m} .4$ appears neither in the first autograph nor the fair copy. The one in $\mathrm{m} .7$, however, appears in both, although in the fair copy it is placed only in the second quarter of the measure (above the triplet). Both the first edition (1913) and Gesamtausgabe (Schönberg 1968) place the "poco rit." at the beginning of $\mathrm{m}$. 7. It is admittedly unclear whether the tempo modification is local and temporary, i.e. whether the "poco rit." should continue until m. 9.

Return to text

57. The letter restricts the fast tempo initially to the first six or nine measures (the typed measure number 7 is crossed out and replaced with a handwritten 10), and then to the first three bars: "The fifth: very 'fliessend' in the beginning, also somehow 'rauschend.' The change in the mood (Reflexion) in bar 710 and the following I start somehow hesitatingly. Back to the first tempo in bar 12, but 'put on the brakes' immediatel[y], of course. [. . .] The fifth: I start about Achtel 144, stating 'in ganzen Takten,' the 4th bar already somehow different (in Achteln). Hardly possible (for me) to play in one te[m]po" (Steuermann 1942).

Return to text

58. That Gould's interpretation displays a certain distancing from the six pieces' aesthetic of immediacy and compression is certainly implicit in his purposefully "illogical” formal molding. A skepticism towards this cycle is manifest in the pianist's essay on Schoenberg's piano music, which was written in the year after his studio recording of op. 19. Here he characterizes the movements of op. 19 as "puzzling, even infuriating little pieces [. . .]. Suddenly, the art of the miniaturist was prospering; pianissimos proliferated, and rests acquired fermatas. A new day of Augenmusik was at hand. It was, of course, an escape hatch, an emergency exit for the uncomfortable stowaways aboard the good ship Post-Wagnerian Romanticism" (1984, 125).

Return to text

59. Reference can also be made to the chapter on quartal chords in Schoenberg's Harmonielehre, which was completed parallel to the composition of op. 19. See Schoenberg [1911] 1922, 476-92 (Schoenberg [1911/22] 1978, 399-410). See also McKee 2005, 131-33.

Return to text

60. This idiosyncrasy is also sketched in the letter to Gielen: “The last: about Viertel 50, but bars 7 an[d] 8 probably a little more moved, the last bar exactly like the first" (Steuermann 1942).

Return to text

61. See footnote 60 .

Return to text

62. The decision to include Karl Steiner's curve instead of the even faster interpretations from Harris 1951 (62.1 bpm; 0:51) or Kraus 1960 (61.7 bpm; 0:47) is justified. Steiner's recording has the shortest total duration of all considered recordings at only 3:58, and the high density of events in 
no. 6 occurs in the context of a tempo conception based on shortening and sharpening of the tempo throughout. Comparatively, in Harris and Kraus, a spontaneous and "irrational" approach takes the foreground, as discussed above. Including Steiner here also has the benefit of at least partially involving another representative of the Second Viennese School in the discussion.

Return to text

63. See Utz forthcoming for a more detailed discussion of recording technique and the historical circumstances of the six Steuermann recordings.

Return to text

64. In the recording from 1949, these accents are actually disruptive, and undoubtedly largely caused by the miking, about which Steuermann repeatedly complained. In the studio recording 1957a, these chords are played with a significantly softer attack, even if occasional light accents are difficult to avoid. In his letter to Gielen, Steuermann refers to this technical challenge: “The last piece as 'etheric' and soft as possible. The chords are difficult in touch as the sound has to be lang and the 'percussion' softened as much as possible" (1942).

Return to text

65. See Repp 1992, Widmer 2002, and Widmer et al. 2003.

Return to text

66. The colors used here cannot appeal to a factor analysis of the entire cycle. Such an analysis was indeed performed, though with unusable results, as the different interpretations do not materialize clear factors over the course of the entire cycle, and thus, with very few exceptions, only the varying correlations with a single "primary factor" remain (only the recordings Harris 1951, Kraus 1960, and Majlingová 1977, often mentioned here already as "outliers," show higher values for a second factor; it remains unclear, however, whether a substantial commonality between these recordings is really captured in this factor). Nonetheless, the attribution of the colors green ("factor 1," Henck 1994), orange ("factor 2," Pollini 1974), red ("factor 3," Gould 1965), and gray ("factor 4," Kraus 1960) should be understood on the basis of a general tendency of these four recordings - that must be further differentiated - as has become clear in the preceding discussion.

Return to text

67. "durch ein zügig veranschlagtes Grundtempo auf das Ganze des musikalischen Verlaufs der Stücke."

Return to text

68. According to Kolisch, the Wiener espressivo consists "above all in the element of construction" $(1983,35)$.

Return to text

69. “Jeder Gedanke [muss] so dargestellt werden, dass das Auffassungsvermögen des Zuhörers zu folgen imstand[e] ist."

Return to text

70. "Klarheit, Klang und Plastik der Darstellung." Sammelprogramm (November 1921), Arnold Schönberg Center, T84.01, cited in Feß 2018, 32.

Return to text

71. "die bis zur Analyse artikulierte Erkenntnis darzustellender Musik;" "Durchleuchtung der besonderen Struktur des konkreten Stücks;" "erhebliche Gehemmtheit;" "Sein Interpretationsideal hatte den Horizont der heraufdämmernden Uninterpretierbarkeit der Werke, so wie die Kafkaschen Parabeln inspiriert sind von der Verdunkelung der heiligen Texte."

Return to text

72. In their analysis of Steuermann's 1949 recording of op. 19, no. 4, Daphne Leong and Hunter Ewen state that "Steuermann's recording treats the score fairly loosely: score details and largerscale shaping seem to be subsumed by local color and rubato, and even a little technical unsteadiness at the end of m. 10. [. . . Clearly, Steuermann does not intend his performance to be a 
sonic image of the score. Rather, his pedaling, rubato, and larger shaping produce a threedimensional, textural, and somewhat romantic interpretation" $(2019,89)$. It should be emphasized that Steuermann's freedom in performance always remained bound to criteria based on an indepth analysis of the score. As outlined above (see [2.8-2.13]), the principle of faithfulness to the musical text within the Second Viennese School's theory of performance should not be (mis)understood in a narrow "literalist" manner but rather as an integrated approach that acknowledges "aspects of performance that are not or cannot be notated" [2.8].

Return to text

\section{Copyright Statement}

Copyright $@ 2020$ by the Society for Music Theory. All rights reserved.

[1] Copyrights for individual items published in Music Theory Online (MTO) are held by their authors. Items appearing in MTO may be saved and stored in electronic or paper form, and may be shared among individuals for purposes of scholarly research or discussion, but may not be republished in any form, electronic or print, without prior, written permission from the author(s), and advance notification of the editors of MTO.

[2] Any redistributed form of items published in MTO must include the following information in a form appropriate to the medium in which the items are to appear:

This item appeared in Music Theory Online in [VOLUME \#, ISSUE \#] on [DAY/MONTH/YEAR]. It was

authored by [FULL NAME, EMAIL ADDRESS], with whose written permission it is reprinted here.

[3] Libraries may archive issues of MTO in electronic or paper form for public access so long as each issue is stored in its entirety, and no access fee is charged. Exceptions to these requirements must be approved in writing by the editors of $M T O$, who will act in accordance with the decisions of the Society for Music Theory.

This document and all portions thereof are protected by U.S. and international copyright laws. Material contained herein may be copied and/or distributed for research purposes only.

Prepared by Sam Reenan, Editorial Assistant

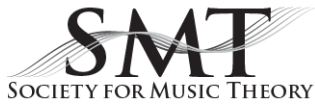

